UNIVERSIDADE DE SÃO PAULO

ESCOLA DE ENFERMAGEM DE RIBEIRÃO PRETO

DEPARTAMENTO DE ENFERMAGEM PSIQUIÁTRICA E CIÊNCIAS HUMANAS

\title{
A PERCEPÇÃO DO CUIDAR ENTRE ESTUDANTES E PROFISSIONAIS DE ENFERMAGEM
}

ROSA APARECIDA PAVAN BISON

RIBEIRÃO PRETO

2003 
Ficha Catalográfica

Bison, Rosa Aparecida Pavan

A percepção do cuidar entre estudantes e profissionais de Enfermagem.

Ribeirão Preto, 2003.

$109 \mathrm{p}$.

Orientadora: Antonia Regina F. Furegato.

Tese ( Doutorado)- Escola de Enfermagem de Ribeirão Preto - USP. Programa de Pós- Graduação em Enfermagem Psiquiátrica.

Bibliografia: p. 101- 109.

1- Cuidar 2- cuidado 3-enfermagem 4- percepção. 


\section{UNIVERSIDADE DE SÃO PAULO \\ ESCOLA DE ENFERMAGEM DE RIBEIRÃO PRETO}

DEPARTAMENTO DE ENFERMAGEM PSIQUIÁTRICA E CIÊNCIAS HUMANAS

\section{A PERCEPÇÃO DO CUIDAR ENTRE ESTUDANTES E PROFISSIONAIS DE ENFERMAGEM}

Tese de doutorado apresentada ao Programa de Pós-Graduação em Enfermagem Psiquiátrica do Departamento de Enfermagem Psiquiátrica e Ciências Humanas da Escola de Enfermagem de Ribeirão Preto, da Universidade de São Paulo para obtenção do Grau de Doutor em Enfermagem.

Aluna: Rosa Aparecida Pavan Bison

Orientadora: Prof. Dra. Antonia Regina F. Furegato 


\section{UNIVERSIDADE DE SÃO PAULO \\ ESCOLA DE ENFERMAGEM DE RIBEIRÃO PRETO}

DEPARTAMENTO DE ENFERMAGEM PSIQUIÁTRICA E CIÊNCIAS HUMANAS

Este trabalho vincula-se à linha de pesquisa Estudos Sobre a Conduta Ética e o Saber em Enfermagem, do Programa de Pós-Graduação em Enfermagem Psiquiátrica do Departamento de Enfermagem Psiquiátrica e Ciências Humanas da Escola de Enfermagem de Ribeirão Preto Universidade de São Paulo. 


\section{UNIVERSIDADE DE SÃO PAULO \\ ESCOLA DE ENFERMAGEM DE RIBEIRÃO PRETO}

DEPARTAMENTO DE ENFERMAGEM PSIQUIÁTRICA E CIÊNCIAS HUMANAS

\section{SUMÁRIO}

Resumo

Abstract

Resumen

Lista de Figuras

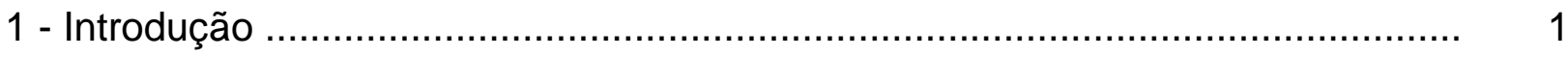

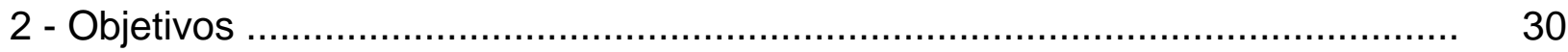

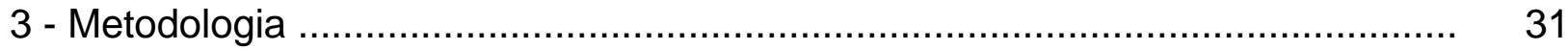

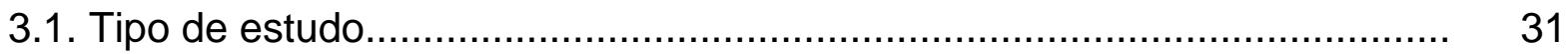

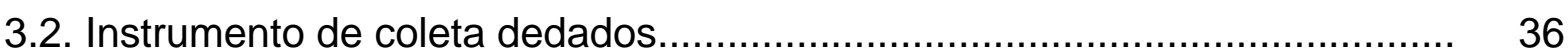

3.3. Procedimentos éticos.............................................................................. 43

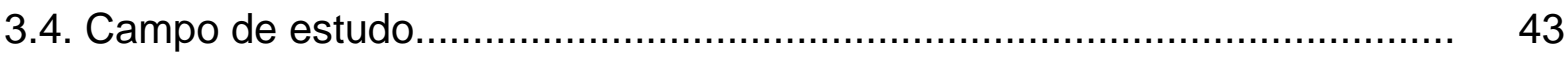

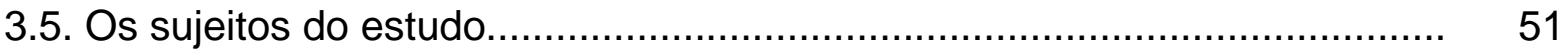

3.6. Procedimentos de coleta dos dados..................................................... 53

3.7. Procedimentos de análise dos dados.................................................... 54

4 - Apresentação e Análise dos Resultados ...................................................... 56

4.1. Perfil da amostra ........................................................................ 56

4.2. Análise estatística da escala................................................................. 62

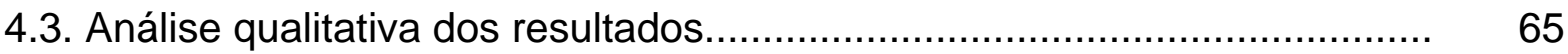

5 - Considerações Finais............................................................................. 92

6 - Referências Bibliográficas ……................................................................ 101

7 - Anexos 


\section{UNIVERSIDADE DE SÃO PAULO \\ ESCOLA DE ENFERMAGEM DE RIBEIRÃO PRETO}

DEPARTAMENTO DE ENFERMAGEM PSIQUIÁTRICA E CIÊNCIAS HUMANAS

\section{Índice de Tabelas}

Tabela 1 Distribuição dos sujeitos participantes da pesquisa, segundo vinculação institucional.....

Tabela 2 Distribuição das medianas das respostas dos grupos de sujeitos, nas 5 categorias de concepção de cuidado na enfermagem.

Tabela 3 Apresentação dos resultados do Quiquadrado e nível de significância de respostas dos sujeitos nas 5 categorias de concepção de cuidado..

Tabela 4 Resultados das respostas dos 4 grupos de sujeitos às 9 afirmativas sobre o significado do cuidar como característica humana.

Tabela 5 Resultados das respostas dos 4 grupos de sujeitos às 9 afirmativas sobre o significado do cuidar como imperativo moral.

Tabela 6 Resultados das respostas dos 4 grupos de sujeitos às 9 afirmativas sobre o significado do cuidar como afeto.

Tabela 7 Resultados das respostas dos 4 grupos de sujeitos às 9 afirmativas sobre o significado do cuidar como relação interpessoal.

Tabela 8 Resultados das respostas dos 4 grupos de sujeitos às 9 afirmativas sobre o significado do cuidar como intervenção terapêutica.

Tabela 9 Resultados das respostas dos grupos em relação às características estudadas. 


\section{UNIVERSIDADE DE SÃO PAULO \\ ESCOLA DE ENFERMAGEM DE RIBEIRÃO PRETO}

DEPARTAMENTO DE ENFERMAGEM PSIQUIÁTRICA E CIÊNCIAS HUMANAS

\section{Índice de Gráficos}

Gráfico 1 Distribuição das respostas dos sujeitos às 9 afirmativas relativas ao conceito do significado do cuidar como característica humana...

Gráfico 2 Distribuição das respostas dos sujeitos às 9 afirmativas relativas ao conceito do significado do cuidar como imperativo moral.......

Gráfico 3 Distribuição das respostas dos sujeitos às 9 afirmativas relativas ao conceito do significado do cuidar como afeto...

Gráfico 4 Distribuição das respostas dos sujeitos às 9 afirmativas relativas ao conceito do significado do cuidar como relação interpessoal.......

Gráfico 5 Distribuição das respostas dos sujeitos às 9 afirmativas relativas ao conceito do significado do cuidar como intervenção terapêutica.

Gráfico 6 Distribuição dos resultados dos grupos em sua totalidade em relação às características estudadas. 


\section{UNIVERSIDADE DE SÃO PAULO ESCOLA DE ENFERMAGEM DE RIBEIRÃO PRETO \\ DEPARTAMENTO DE ENFERMAGEM PSIQUIÁTRICA E CIÊNCIAS HUMANAS}

Data da Defesa: 23/07/2003

\section{Banca Examinadora}

$\operatorname{Prof}^{\mathrm{a}} \mathrm{Dr}^{\mathrm{a}}$ Antonia Regina Ferreira Furegato

Julgamento: Assinatura:

Prof $^{a}$ Dr $^{\mathrm{a}}$ Renata Curi Labate

Julgamento: Assinatura:

Prof. Dr. Jair Lício Ferreira Santos

Julgamento: Assinatura:

Prof $^{a}$ Dr $^{\mathrm{a}}$ Marli Villela Mamede

Julgamento: Assinatura:

Prof $^{\mathrm{a}}$ Dr ${ }^{\mathrm{a}}$ Márcia Niituma Ogata

Julgamento: Assinatura: 


\section{AGRADECIMENTOS}

\section{À Prof.Dra. Antonia Regina F. Furegato,}

amiga e orientadora, pelo carinho, atenção e profunda sabedoria com que guiou meus passos até este marco importante.

\section{Aos professores}

Dr. Luiz Jorge Pedrão,

Dra. Ana Maria Pimenta Carvalho

Dr. Moacir Lobo da Costa Junior e

Dr. Jair Lício Ferreira Santos

pelas importantes sugestões e orientações que enobrecem o meu estudo.

Aos professores, enfermeiros e alunos, pela ativa participação e contribuição para a consecução deste trabalho.

\section{À Marina Álvares Leite Denardi,}

pela efetiva colaboração nas discussões e elaboração deste trabalho.

\section{À Gilda Cheida Pereira de Souza,}

pelo companheirismo e amizade fraterna, estimulando-me dia a dia.

\section{À Márcia Pavan,}

querida irmã pelo constante apoio e afeto. 


\section{DEDICATÓRIA}

Ao Jorge Luiz, ao Henrique José,

à Rosana Maria,

Amores supremos da minha vida.

Ao Tite e à Dulce

Queridos pais.

Dedico este trabalho, resultado da minha trajetória profissional. 


\section{RES U M O}

BISON, R.A.P. A percepção do cuidar entre estudantes e profissionais de enfermagem. 2003. Tese de Doutorado - Escola de Enfermagem de Ribeirão Preto, Universidade de São Paulo, Ribeirão Preto.

Este estudo objetivou conhecer a percepção do cuidado e as correlações entre as concepções do estudante de enfermagem, do enfermeiro e do professor de enfermagem através de um instrumento, construído com base nos conceitos e classificações de MORSE (1990). Seus trabalhos contêm definições de cuidado, evidenciadas através de técnicas de esclarecimento, envolvendo o cuidar como uma característica humana, como um imperativo moral ou ideal, como afeto, como relação interpessoal e como ação terapêutica de enfermagem. $O$ instrumento foi elaborado, após análise sistemática de 227 redações de alunos de enfermagem, sobre o cuidado e seus significados. As 50 afirmativas, selecionadas, agrupadas por categoria, foram por duas vezes analisadas por juízes e o índice de desempenho por fator. O instrumento final, sob a forma de uma escala ordinal tipo Likert de cinco pontos de concordância sobre o objeto psicológico, recebeu o nome de Escala de Avaliação do Significado do Cuidar (EASC), com 45 afirmativas, distribuídas pelas cinco categorias (característica pessoal humana, imperativo moral, afeto, relação interpessoal e intervenção terapêutica), com nove proposições em cada uma. Os 171 sujeitos foram alunos dos cursos de graduação e especialização da UNIARARAS, enfermeiros atuantes em instituições de saúde de Araras/SP e docentes do curso de Enfermagem, da UNIARARAS. Os dados foram digitados e processados através de programas informatizados, específicos para o estudo; receberam tratamento estatístico para que fosse possível analisar a existência ou não de diferenças entre os grupos de sujeitos e as categorias. Foram calculados os valores das freqüências absolutas e percentuais das respostas de cada sujeito, por grupo e por categoria, calculadas as medianas e o nível de significância e empregada prova não paramétricas de KruskalWallis para verificar se eram significantes as diferenças entre os quatro grupos. Igualmente testouse, dentro de cada grupo, a eventual diferença entre categorias. Nos grupos, as maiores diferenças evidenciam-se entre as concepções de alunos e professores. Nas categorias, no seu conjunto, os escores de professores e alunos são próximos assim como os de especializandos e enfermeiros da prática, com diferenças significativas entre os dois agrupamentos. As diferenças são mais evidentes na concepção de cuidado como característica pessoal humana e como imperativo moral. A discussão dos resultados conduz para a necessidade de maior afinação entre o embasamento teórico ministrado no ensino e sua aplicação no exercício efetivo da profissão.

Palavras chaves: cuidar, cuidado, percepção, enfermagem, avaliação. 


\begin{abstract}
BISON, R.A.P. The perception of caring among nursing professionals and students.2003. Doctorate Thesis - School of Nursing of Ribeirão Preto, São Paulo University, Ribeirão Preto.
\end{abstract}

The purpose of this study was to apprehend the perception of caring and its correlations with the process of caring in the conception of the professor of nursing, the student of nursing and the nurse, through an instrument developed on the basis of Morse's concepts and classifications( MORSE (1990)), which contain implicit and explicit definitions of care, evidenced through clarification techniques that had allowed the explanation of five ontological classifications: Caring of as a characteristic human being; b) Caring as a moral or ideal imperative; c) Caring as affection; d) Caring as interpersonal relation; and e) Caring as therapeutical action of nursing. The instrument, named Scale of Evaluation of the Meaning of Caring (EASC), was elaborated after systematic analysis of 227 writings of students of the courses of graduation and specialization in nursing, about caring and its meanings, from which we extracted a great number of affirmative phrases and selected them, grouping 10 for category to be analyzed. Then the instrument was formatted, under the form of an ordinal scale Likert type of 5 points, with the same order. Likert supports that an attitude (psychological property) constitutes a disposal for the action). We verified the degree of adhesion of the individual to the series of affirmations to be answered, in a scale where he has to say if he agreed, was in doubt or disagreed in face of the affirmation on the psychological object.The final version was a scale with 45 affirmations, distributed for the 5 categories, with 9 proposals in each one. The answers were registered through a software adjusted for manipulation of the data, and we then got the values of the absolute and percentile frequencies of the answers of each citizen, for group and category, and calculated the mean rates and the level of significance. The statistical tests were used to verify if the differences between the 4 groups were or not significant. Equally it was tested, inside each group, the eventual difference between categories. The data were registered and analyzed, typed and processed through specific programs for this study, receiving statistical treatment so that it was possible to analyze the existence or not of differences between the groups and the categories. The results showed differences among the groups, implying that what is thought in the university is not in consonance with the reality seen in a profession which since the last decade of the $\mathrm{XX}$ th century has considered caring as the referencial landmark in a new paradigm of nursing. This approach, despite the relevance for the profession, has not received attention on the part of who teaches it, who practises it and who receives it.

Key words: care, caring, perception, nursing, evaluation. 


\section{RESUME}

BISON, R.A.P. La percepción del cuidar ente estudiantes y profesionales de enfermería, 2003. La Tese de Doctorado, La Escuela de Enfermerìa de Riberòn Preto, Universidad de San Paulo, Riberòn Preto.

Este estudio tiene como objetivo conocer la percepción del cuidado y las correlaciones entre las concepciones del estudiante de enfermería, del enfermero y del profesor de enfermería, a través de un instrumento, construido con base en los conceptos y clasificaciones de MORSE (1990), Sus trabajos contienen definicione de cuidados, evidenciadas atraves de técnicas de esclarecimientos, envolviendo el cuidar como una característica humana, como un inperativo moral o ideal, con afecto, con una relación interpersonal; y con acción terapeutica de enfermería. El instrumento fue elaborado después de un análisis sistemático de 227 redacciones de alumnos de enfermería, sobre el cuidado y sus significados. Las 50 frases afirmativas seleccionadas y agrupadas por categoría fuerón dos vezes analizadas por juezes y el indice de desenpeño por factor. El instrumento final elaborado sobre la forma de una escala ordinal tipo tikert de 5 puntos de concordancia sobre el objeto Psicologíco, recibio el nombre de Escala de Avaliación de significados del cuidar (EASC), la misma que cuenta con 45 frases afirmativas, distribuídas por las 5 categorias (característica personal humana, Imperativo moral, afecto, relación interpersonal e intervención terapeutica ), con 9 proporsiciones en cada una. Los 171 individuos fueron alumnos de los curso de graduación y especialización de la universidad, UNIARARAS, enfermeros que actuan en instituiciones de salud en la ciudad de Araras/SP y docentes del curso de enfermería de la UNIARARAS. Los datos fuerón digitados y procesados a través de programas informatizados, específicos para el estudio, recibiendo un tratamiento estatístico, para que fuera posible analizar la existencia o no de diferencia entre los grupos de individuos y las categorías. Fuerón calculados los valores de las freqüencias absolutas y porcentajes de las respuestas de cada individuo por grupo y por categoría, calculando la media y el nível de significancia para esto fuerón empleadas pruebas no paramétricas de Kruskal-Wallis para verificar si eran significantes las diferencias entre los 4 grupos. Igualmente se testo, dentro de cada grupo, la eventual diferencia entre categorías. En los grupos las mayores diferencias se evidenciarón entre las concepciones de alumnos y profesores; en las categorías en conjunto la diferencia entre profesores y alumnos son próximas, asi como los de alumnos de especialización y enfermeros, con diferencias significativas entre los dos grupos. Las difefencias son màs evidentes en la concepción del cuidado como característica personal humana y como imperativo moral. La discusión de los resultados nos conduzen para la necesidad de mayor afinación entre el material teorico administrado en el enseño y su aplicación en el ejercicio efectivo de la profesión.

Palabras claves: cuidar, cuidado, percepción, enfermería, avaliación. 


\section{1- INTRODUÇÃO}

\section{a) A escolha do tema}

O interesse pelo ensino e pela aprendizagem, com enfoque no aluno, faz parte de nossa trajetória profissional, o que tem sido um fato instigante, uma busca que funciona como um estímulo para continuar aperfeiçoando o conhecimento nesta temática.

Os resultados de nossa dissertação de mestrado, parte integrante deste caminhar, apontaram esse norte como uma direção possível. Acreditamos que a enfermagem como profissão, tem o homem como seu centro de preocupação; o ato do cuidar, seu marco referencial; a crescente melhoria da qualidade de vida, sua meta de trabalho; e as áreas do conhecimento que privilegiam o ser humano ecológico, o domínio do seu saber (BISON, 1998).

Nas conclusões do nosso estudo acima citado, observa-se a necessidade constante de conhecer e experimentar novas teorias e rever antigos conceitos, neles incorporando as tecnologias que surgem e a atualização dos métodos éticos, a fim de adequadamente preparar aqueles que se dispõem a exercer a enfermagem que presta o cuidado na sua mais completa acepção semântica, hermenêutica e simbólica, ou seja, com 
consciente atenção e diligência, zelo e previsão, reflexão e responsabilidade no agir.

Enaltecemos que o cuidado ao ser humano não pode continuar sendo uma meta, mas a essência da prática do ensino da enfermagem, nele incluso o próprio agente (a enfermeira), que tem de descartar falsos valores, ciente de que somente será agente de mudança, se se transformar a si mesma.

Para Heidgger (1970), nenhuma época acumulou sobre o homem conhecimentos tão numerosos e tão diversos como a nossa, mas também, época nenhuma soube menos o que é o homem.

Pensamos que o conhecimento não é sinônimo de mera informação, adesão a uma teoria, engajamento em uma corrente filosófica; é, antes, dar sentido ao mundo.

A atividade de dar sentido é sempre cognitiva e afetiva e implica o uso de conexões neurais habituais, desenvolvidas tanto pela experiência quanto pela emoção.

O equilíbrio e a harmonia das nossas forças vitais começam na complexa co-gestão da vida factual e das emoções de cada um.

Na verdade, o bem-estar humano é um processo dinâmico, enfatizado pela filosofia ecológica, que vê o ser humano como um todo inseparável do cosmo: não se pode compreender espírito e mente, emoção e corpo físico, isoladamente.

Falar sobre um tema é sempre uma produção de sentido, pois cotidianamente buscamos nos repertórios de nossa própria história um 
sentido. A nossa busca, aqui, é exatamente a desse rumo. Desse prumo. Desse signo.

Neste caminho ascendente a permear-me a vida, encontrar nos relicários mais significativos e sagrados, o sentido do cuidar em enfermagem, que é a minha meta, só tem acrescentado ao meu viver um grande incentivo.

A enfermagem como profissão firmou-se de forma significativa no último século, transpondo os liames do atual como uma área científica de prestação de serviços, voltada ao cuidado do outro.

Como bem ressaltou Peplau (1997), em seu discurso no $21^{\circ}$ Congresso Quadrienal do CIE (Comitê Internacional de Enfermeiras) em Vancouver, Canadá:
A questão que dominou o século $X X$ era "o que as enfermeiras fazem?" No próximo século, a questão passará a ser "o que as enfermeiras sabem e como elas usam esse conhecimento para beneficiar as pessoas?".

Segundo Minayo (1977), 80\% de todo o impacto científico no mundo de produção aconteceu depois da Segunda Guerra Mundial e 50\% do que estaremos usando na primeira década deste novo século ainda não foi inventado, existindo um lapso cada vez menor entre a concepção e o uso dos objetos. Em países desenvolvidos e altamente industrializados esse interstício é mais curto do que o tempo de formação de um profissional universitário. 
Nas sábias palavras de Vannucchi (1977), em cerca de dez mil anos de história, o mundo atual é aquele em que o homem se torna completa e totalmente problemático para si mesmo, visto que não sabe mais o que é, mas ao mesmo tempo sabe o que não é.

Numa era globalizada, com a intensidade e a rapidez das informações tecnológicas e científicas tornando impossível a absorção de tantos conhecimentos, os modelos de formação que temos tornam-se anacrônicos. Nesse sentido Minayo (1997) chama a atenção para as propostas de novos valores e amplas perspectivas e Morin (1996) denomina Paradigma da Complexidade o rompimento do ensino academicista com o saber centrado no professor.

Devido à velocidade e à intensidade com que o mundo globalizado acessa a informação, torna-se cada vez mais importante atentarmos para recortes bem definidos nas áreas de conhecimento, pois dessa forma garantiremos maior densidade de conteúdo.

O foco da enfermagem como ciência ainda não está claramente definido, mas é emergente na centralização dos conceitos de cuidar e de saúde.

Uma área da ciência, para Newman (1991), é distinguida por um domínio de questionamentos, que representa uma crença compartilhada por seus membros, no que tange à sua razão de ser.

Por outro lado uma disciplina profissional é definida pela relevância social e orientação de valores envolvendo seu comprometimento social, a 
natureza de seus serviços e suas áreas de responsabilidade para desenvolver o conhecimento.

Todo conhecimento procede de perspectivas filosóficas e cientificas, ou seja, visões de mundo. Na enfermagem, urge que coloquemos em discussão os paradigmas da concepção profissional, para que possamos aprimorar o conhecimento próprio da atividade.

Desde a sua fundamentação em 1860, por Nightingale, a enfermagem como disciplina profissional vem buscando a sedimentação do seu saber, tendo a pessoa como centro. Nas últimas décadas, o trinômio: pessoa, ambiente e saúde permeou-Ihe a atenção, os estudos e a prática.

No o final da década de 90 novos ângulos, saúde e cuidado, passaram a ser estudados com maior ênfase, com inúmeros trabalhos desenvolvidos a partir da Conferência de Wingspread, centrada nos conceitos do cuidar na enfermagem, levantando questões que ainda carecem de respostas satisfatórias para que o binômio supracitado preencha os requisitos de um saber próprio de domínio da enfermagem (MORSE, 1995, WALDOW, 1992).

O conceito de saúde é sempre ligado a ações e intervenções. Daí a interligação com o cuidar.

Morse (1995) percebe que muito do conhecimento de enfermagem permanece não desenvolvido, implícito, irreconhecível ou inadequadamente encaixado no contexto clínico, salientando a importância de se desenvolver estudos que examinem como as pessoas percebem a saúde, a enfocar, preferencialmente, o que fazem ou como fazem os profissionais da área. 
Para a autora, forçosamente ocorre, para atender às micro e macro perspectivas da área de enfermagem, uma adesão aos princípios de inquirição filosófica, aliada aos padrões das ciências sociais, humanas, biológicas e exatas.

\section{b) Construção teórica}

$\mathrm{Na}$ atualidade, os estudos sobre o cerne da enfermagem têm se desenvolvido acompanhando as transformações por que passa o mundo, exigindo dos profissionais mais reflexões sobre a atividade e uma adequação da prática às novas realidades, possibilita a geração de contradições quando se observa o exercício da atividade desvinculado do uso e/ou acompanhamento da produção de pesquisa.

Em sua raiz histórica de profissão autônoma, a enfermagem apóia-se em duas vertentes: o conhecimento científico e o conhecimento humanístico.

Bettinelli (2002) discute a questão, ponderando que, se por um lado o desenvolvimento científico e tecnológico (principalmente na área da saúde) vem promovendo novas formas de viver com maior conforto, inúmeras possibilidades e muitas esperanças, ele tem produzido, por outro, questionamentos, temores e desafios éticos aos homens. São enfatizadas a produtividade e a flexibilidade como foco, devido à complexidade do processo das organizações e das relações, possibilitando o deslocamento da excelência do ser para o fazer, acarretando um declínio da ética e valores fragmentados. 
As conseqüências dessa modernidade científica a estimular o exploratório e não a conjunção e a congruência, priorizando o particular, em detrimento do geral, e valorizando a especialização, em prejuízo da integração, repercutem na enfermagem, com magnitude.

Newman (1991) indaga: A enfermagem é o estudo do cuidar na experiência de saúde humana. enquanto que, para Martin Heidegger (1997), o filósofo do cuidado, no livro Ser e Tempo, do ponto de vista existencial, o cuidado antecede toda atitude e situação do ser humano, o que significa dizer que o cuidado encontra-se em toda atitude e situação de fato; portanto, um fenômeno antológico, existencial, básico.

Já Boff (1999), vê o cuidado como parte da natureza e da constituição do ser humano, afirmando que o modo de ser cuidado revela, de maneira concreta, como é o ser humano.

Se não receber cuidado, desde o nascimento até a morte, o ser humano desestrutura-se, definha, perde sentido e morre. Assim, sem o cuidado o homem perde sua natureza humana.

Nos quadros depressivos a falta de motivação é expressa através da falta do cuidado de si e do interesse pela vida.

É lugar comum afirmar que o ser humano é essencialmente um ser de necessidades a serem satisfeitas e, por isso, um ser em busca de cuidado, gregário, social, sujeito histórico (pessoal e coletivo) que constrói relações sociais inseridas nas mais diversas condições culturais.

O ser humano vem dotado de sacralidade, dados os seus inalienáveis direitos e deveres, e evolui constantemente rumo ao futuro. Na trajetória 
histórica do seu viver, molda-se mediante a cultura, o meio ambiente, o grupo social a que pertence, introjetando valores, princípios e idealizações que darão origem às suas atitudes, ações e opiniões (BOFF,1999).

Rogers (1982) afirma que o homem em sua constante transformação em busca de equilíbrio, crescimento e amadurecimento, é um ser bom em sua essência.

Para Sung e Silva (1998), a interiorização da cultura da sociedade ou do grupo social a que pertencemos possibilita-nos agir de uma forma instintiva e automática. Segundo eles, a origem de uma cultura está historicamente na exteriorização da primeira geração, a partir da qual surge a tradição, transmitida de geração a geração.

Imagens e símbolos habitam as profundezas do espírito humano, instrumentalizando-lhe as ações. Daí emergem os mitos e as concepções da realidade que norteiam a socialidade humana e identificam a essência frontal do ser.

É pelo cuidado essencial que o ser humano expressa sua complexidade, sua bipolaridade, sua ambivalência, e delas faz amálgama de construção de sua existência no mundo e na história.

O homem é um projeto infinito, e o infinito não se enquadra em qualquer lógica, obrigando-nos a compreender nossa condição de sistema aberto, apto a novas incorporações e vivências.

Falar do cuidado (como é vivido e se estrutura em nós mesmos) é falar da história, de como fomos e somos cuidados, o que evidencia a dimensão antológica do cuidado, elemento constituinte do ser humano. 
Trata-se, para Heidegger (1989), do solo em que se move toda a interpretação do ser humano.

Na visão humanista, não lograremos compreender o ser humano, se não nos basearmos no cuidado. O cuidado do outro requer uma atitude fundamental, um modo de agir em que a pessoa desvincula-se de si própria e centra-se no outro, com desvelo e solicitude.

Para Horácio (65-8 AC) apud Heidegger (1989), o cuidado é o permanente companheiro do ser humano, que nunca deixará de amar e de se desvelar por alguém. No outro extremo pode-se dizer que a indiferença é a morte do amor e do cuidado.

O cuidado permite ao ser humano viver a experiência fundamental do valor daquilo que o cerca, que tem importância e definitivamente conta, ou seja, o valor intrínseco de cada coisa.

No modo de cuidar ocorrem resistências e emergem perplexidades, que são superadas pela paciência perseverante. No lugar da agressividade tem-se a convivência amorosa e, em vez da dominação, a companhia afetuosa, ao lado e junto do outro.

Pessini (2000), um estudioso da ética e da bioética, mostra como exemplo a fábula de Higino, que enfatiza o cuidado acompanhando o ser humano durante toda a sua vida, ao longo de todo o seu percurso temporal no mundo. A fábula diz que o cuidado foi quem primeiro moldou o ser humano, empenhando dedicação, ternura, devoção, sentimento e coração. Com isso, criou responsabilidades e fez surgir a preocupação com o ser que ele plasmou. Essas dimensões,verdadeiros princípios constituintes, entraram 
na composição do ser humano. Viraram carne e sangue. Sem tais dimensões o ser humano jamais seria humano.

Boff (1999) ressalta que injetar cuidado em tudo é imprescindível para desenvolver a dimensão humana. Significa conceder direito de cidadania à nossa capacidade de sentir o outro, ter compaixão por todos os seres que sofrem, humanos e não humanos, obedecer mais à lógica do coração, da cordialidade e da gentileza do que à da conquista e do uso utilitário das coisas.

O autor faz um inventário das muitas ressonâncias do cuidado, quais sejam: 1- O amor como fenômeno biológico; 2- como a justa medida; 3como a ternura vital; 4- como a carícia essencial; 5- como a cordialidade fundamental; 6- como a convivialidade necessária; 7- como a compaixão radical. O cuidado significa uma relação de amorosidade com o mundo real, com tudo aquilo que tem valor e interesse para nós, exigindo total atenção e desvelo, comprometimento e envolvimento, despertando preocupação e inquietação.

Dada a atual diversidade nas conceitualizações do cuidar, todas as tentativas para delineá-lo podem se aplicar de alguma forma ao paradigma central da enfermagem.

Segundo Morse (1995), os conceitos filosóficos são expressões dos modos como a experiência se tornou organizada, vindos da intenção do sujeito. São resultados de instâncias particulares, que se tornaram gerais, por serem tratadas como exemplos de um tipo ou regra, significados gerais que são estabilizados com o uso da linguagem em interação social. 
Esses conceitos devem ser examinados, em sua formação, sob a ótica da correlação emergente entre os atos e as condições de estímulo às quais estão relacionados, havendo uma relação recíproca entre os atos interpretativos pelos quais construímos nossos modelos de realidade e as propriedades da realidade em si.

A enfermagem pouco tem se voltado para os conceitos filosóficos do cerne da profissão e, na questão específica do tema deste estudo, não é abrangente o bastante para englobar todos os componentes do cuidar, necessários para orientar a fundamentação de um saber específico. Permanece um elo solto entre as muitas definições e os resultados, ou o efetivo cuidado ao cliente.

Algumas teoristas de enfermagem voltam-se para as questões epistemológicas da enfermagem, mas a evolução das pesquisas tem maior desenvolvimento no âmbito das tecnologias e das ciências aplicas.

A pesquisa de enfermagem, segundo Newman (1991), tem sido conduzida a partir de uma orientação contendo pelo menos três paradigmas, que refletem a mudança de foco, do físico para o social e deste para as ciências humanas, a saber:

- Particular - determinista;

- Interativo - integrador;

- Unitário - transformador.

$\mathrm{Na}$ perspectiva particular-determinista, os fenômenos podem ser vistos como isoláveis, entidades reduzíveis, com propriedades definíveis, que podem ser medidas. 
Na visão da perspectiva interativo-integradora, são levados em conta o contexto, a experiência e os dados subjetivos legitimizados; os fenômenos são vistos como detentores de partes múltiplas, inter-relacionadas em relação a um contexto específico. Assim, a realidade é tida como multidimensional e contextual.

A terceira perspectiva, unitário-transformadora, representa uma mudança significativa de paradigma. A partir dela, um fenômeno é visto como área unitária, auto-organizadora, e é identificado por padrão e interação com o todo mais amplo.

O foco de uma disciplina profissional é uma área de estudo definida pelo comprometimento social e de serviço, compartilhado em uma profissão. Um foco unificado, derivado da união de teorias sobre o cuidar e a saúde, tem o potencial de requerer a visão compartilhada de enfermagem.

Pensa-se hoje em formar profissionais criativos, com habilidades de resolutividade, reflexivos, num espaço acadêmico interativo, com professores e alunos interferindo na realidade.

No Documento de Políticas para as mudanças e o desenvolvimento da educação superior, a UNESCO (1995) preconiza um novo paradigma acadêmico, formando profissionais que promovam melhor qualidade de vida da população.

O referido documento enfatiza a discussão da realidade profissional inserida na problematização regional, sem perder de vista a reflexão sobre as transformações sociais que a globalização gera, mas viabilizando a "resolução de problemas comprometidos com a verdade, da defesa e 
fomento de direitos humanos, da democracia, da justiça social e da tolerância, rumo ao desenvolvimento humano sustentável" (UNESCO, 1995).

A enfermagem tem o dever de encontrar o seu espaço, buscar sua identidade, resgatando suas raízes, para construir uma disciplina voltada ao seu foco principal: o cuidado humano.

A enfermagem brasileira, pouca atenção tem dado ao estudo do significado do cuidado, na visão de Waldow (1992), para quem é necessário investigar os componentes culturais do cuidado na nossa sociedade, principalmente no tocante a como ele é percebido, expresso e vivido profissionalmente. Da mesma forma, é de suma importância também canalizarmos estudos, segundo a autora, quanto à abordagem do ensino do cuidado, tanto na teoria, quanto na prática acadêmica de enfermagem.

Morse (1991) não encontrou consenso em relação às definições, em relação aos componentes, ou mesmo em relação ao processo do cuidar, e, segundo Arruda (1994), o assunto não tem merecido a atenção necessária por parte dos enfermeiros. Urge pesquisas e estudos que desenvolvam esse conhecimento. Somos concordes com este posicionamento, tendo em vista que através do ensino forjar-se-á os futuros profissionais de cada profissão.

Gamboa (1997) fala que cuidar compreende vasta concepção, mas, na enfermagem, a perspectiva biológica tem sido a mais comum. Essa concepção envolve um determinismo tecnicista, em que são priorizados tempos e movimentos, em detrimento de fatores preponderantes, como a emoção e a relação interpessoal. 
Dupas(1999) também afirma que cuidar, assim, não é a concentração na pessoa a ser cuidada, mas nos procedimentos técnicos a serem efetuados.

Gamboa (1997) preconiza que cuidar não é um ato único, nem mesmo a soma de procedimentos técnicos ou qualidades humanas. Trata-se do resultado de um processo em que se conjugam sentimentos, valores, atitudes e princípios científicos, com a finalidade de satisfazer os indivíduos nele envolvidos.

A enfermagem é acima de tudo uma disciplina contextual que emerge da filosofia prática, uma área que tem recebido incentivo para investir em seus pares, através de aperfeiçoamento, especialização, pós-graduação profissionalizante e strictu-sensu. O ensino superior é, em qualquer sociedade, um dos motores do desenvolvimento econômico e cultural, um dos pólos a ser atingido pelas pessoas.

A enfermagem como profissão deve definir sua cultura, ou seja, quais os produtos decorrentes de sua atividade, sejam materiais ou espirituais, concretos ou subjetivos, para poder delinear o perfil de sua formação. Para Waldow (1992), o enfoque principal é o cuidado, que deve ser discutido dentro de uma perspectiva histórica, em busca de uma identidade que possibilite o seu desenvolvimento como profissão autônoma.

A expressão cuidado/cuidar tem inúmeros sentidos. Na definição de Aurélio (1975), cuidado é sinônimo de atenção, zelo, desvelo, responsabilidade por preocupação para com. Em Volichi (2000) e Gaut 
(1983), tem-se a descrição etimológica do termo, mediante diferentes culturas:

1) do latim: cura, tem o significado de desvelo, de preocupação e de inquietação pela pessoa ou objeto amado; cogitare - cogitatus, que significa cogitar, pensar, mostrar interesse, solicitude, atenção, bom trato;

2) do inglês arcaico: carion tem o sentido de ter preocupação, sentir inclinação, dar preferência, respeitar, considerar, ter afeto, ter simpatia; e

3) do termo gótico: Kara/karon, expressando aflição, pesar, tristeza.

Diante desses significados, pensamos na propositura de estudos que adensassem essa área fundamental do conhecimento em enfermagem.

No presente estudo, adotamos conceitualmente os trabalhos de Morse (1990) que demonstram definições implícitas e explícitas de cuidado, evidenciadas através de técnicas de esclarecimento que permitiram sua explicação através de cinco classificações ontológicas:

a) Cuidar como uma característica humana;

b) Cuidar como um imperativo moral ou ideal;

c) Cuidar como afeto;

d) Cuidar como relação interpessoal;

e) Cuidar como ação terapêutica de enfermagem.

Para chegar às definições e classificações mencionadas, Morse (1995) discute as seguintes questões: O cuidado é único para a enfermagem? O intento de cuidar varia conforme os pacientes? O cuidado pode ser reduzido a tarefas comportamentais? O resultado do cuidado afeta o paciente, a enfermeira, ou ambos? 
Morse (1990) pesquisou e analisou inúmeros trabalhos, buscando encontrar as seguintes manifestações: se o autor considerava o cuidado como traço humano, uma parte da natureza humana, característica básica, integral do ser humano; se era tido como um imperativo moral, uma emoção, um sentimento de compaixão dentro da enfermagem; se significava uma empreitada mútua entre enfermeira e paciente, evidenciada numa interação; e se era percebido como intervenção terapêutica.

A partir da última década do século passado, o cuidado tem sido proposto como o marco referencial em um novo paradigma da enfermagem. Esse conceito, apesar da relevância para a profissão, não tem recebido a devida atenção, em relação ao seu real significado e seus significantes para quem o ensina, quem o pratica e quem o recebe.

A maior parte dos conceitos e definições em enfermagem emergiu nas décadas de 70 e 80, no bojo das grandes transformações sociais e tecnológicas que modificaram as relações humanas.

Segundo Newman (1991), na década de 90 dois conceitos se consagram na enfermagem: saúde e cuidar; e uma disciplina profissional é definida pela sua relevância social, orientação de valores, comprometimento humano, natureza de seus serviços e área de responsabilidade para com o desenvolvimento do conhecimento, que dependerá das diferentes perspectivas filosóficas e científicas. A partir daí, o trinômio: pessoa, saúde e ambiente tornou-se o centro da atenção da enfermagem, delineando sua prática, seus estudos, seu ensino. 
Peplau (1992) afirma que a enfermagem é terapêutica, pois auxilia o indivíduo doente e/ou necessitado de cuidados, através da relação interpessoal, apresentando-se como um agente especialmente preparado para reconhecer essa necessidade de ajuda e a ela responder.

O cuidado está na maioria das vezes ligado ao conceito de saúde e doença, sendo que nas revisões das definições conceituais de cuidado e cuidar, encontramos esse entrelaçamento descrito por diferentes teoristas, entre eles, George (1993) e Leopardi (1999).

George (1993) fala da concepção de Henderson sobre o indivíduo como foco do cuidado, sendo a enfermagem o instrumento para auxiliá-lo através de atividades fundamentais que mantenham a saúde, recuperem-na ou contribuam para uma morte digna. Essa visão contempla os componentes dos cuidados básicos que a enfermagem deve ajudar a garantir às pessoas: respirar normalmente; comer e beber adequadamente; eliminar os dejetos do corpo; caminhar e manter a postura; dormir e descansar; vestir e despir roupas adequadas; manter a temperatura do corpo; manter o corpo limpo e bem arrumado; ambiente sem perigo; comunicação; culto de acordo com a fé pessoal; realização do trabalho; recreação; aprender, descobrir, ou ter sua curiosidade satisfeita.

A teoria de Hall aborda três aspectos: o cuidado, o ser, a cura. Estes três aspectos devem interagir na dimensão da necessidade do paciente (GEORGE, 1993).

O aspecto cuidado tem como meta o conforto do paciente, sendo exclusivo da enfermagem. Entende a teorista que este é o componente 
estimulador, que prepara as atividades de ensino-aprendizagem. Quando este fato se concretiza o paciente estabelece com o enfermeiro uma relação de proximidade e de intimidade para a expressão de sentimentos.

O aspecto do ser é o "uso terapêutico do ego", através do recurso da reflexão. Ao estabelecer uma relação interpessoal com o paciente, o enfermeiro pode ajudá-lo na manifestação de sentimentos que o levem a desenvolver-se.

O aspecto cura focaliza a ação do enfermeiro relacionada a atividades médicas e suas prescrições.

Orem (1985) apresenta, em sua teoria de enfermagem, três construtos que se inter-relacionam: autocuidado, déficit de autocuidado e sistema de enfermagem. A deficiência do autocuidado é a essência desta teoria, pois identifica as necessidades de cuidados de enfermagem, ou seja, quando o indivíduo acha-se incapacitado ou limitado para cuidar de si, contínua e eficientemente.

Para Johnson, como descreve George (1993), o paciente é identificado pelo aspecto comportamental, composto de sete subsistemas: filiação, dependência, ingestão, eliminação, sexo, agressividade e realização. Qualquer interferência em um ou mais subsistemas pode levá-lo ao desequilíbrio.

O cuidado de enfermagem consiste em ações em defesa de um funcionamento comportamental adequado, que previna a doença ou, em caso de algum desequilíbrio, ofereça uma assistência que conduza à homeostase. 
George (1993) também apresenta a teoria de Abdellah, para quem a enfermagem consiste no uso do método de solução de problemas: os problemas-chaves de enfermagem, relacionados às necessidades de saúde das pessoas. Para identificá-los precisamente, classificou-os em três categorias principais: a) necessidades físicas, sociológicas e emocionais dos clientes; b) tipo de relação interpessoal entre o enfermeiro e o cliente; e c) elementos comuns de cuidados de enfermagem.

São vinte e um problemas comuns classificados, com os quais deve se ocupar a enfermagem: manter boa higiene e conforto físico; promover atividades mais favoráveis de exercícios, repouso e sono; promover a segurança, evitando acidentes, ferimentos ou outros traumas e do alastramento de infecções; manter boa mecânica do corpo e prevenir e corrigir deformidades; facilitar a manutenção de um suprimento de oxigênio a todas as células do corpo; facilitar a manutenção de nutrição a todas as células do corpo; facilitar a manutenção da eliminação; facilitar a manutenção do equilíbrio de fluídos e eletrólitos; reconhecer as reações fisiológicas do corpo às condições de doença (patológicas, fisiológicas e compensatórias); facilitar a manutenção de mecanismos e funções reguladores; facilitar a manutenção da função sensorial; identificar e aceitar expressões, sentimentos e reações positivas e negativas; identificar e aceitar a inter-relação entre emoções e doenças orgânicas; facilitar a manutenção. de efetiva comunicação verbal e não verbal; promover o desenvolvimento de relações interpessoais produtivas; facilitar a evolução na direção da conquista de metas espirituais pessoais; criar e/ou manter um ambiente 
terapêutico; facilitar a conscientização de si mesmo como um indivíduo com necessidades físicas, emocionais e de desenvolvimento; aceitar favoravelmente as metas possíveis, frente às limitações físicas e/ou emocionais; usar os recursos da comunidade para auxiliar na resolução de problemas decorrentes da doença; compreender o papel dos problemas sociais como fatores influenciadores, no caso de doenças.

Orlando (1972) enfatiza que a enfermagem auxilia diretamente o paciente, através da satisfação de suas necessidades afetadas ou manifestas, propiciando-lhe amparo e alívio de seu sofrimento, podendo as ações de enfermagem ser automáticas ou voluntárias: as primeiras advêm de razões que não a necessidade imediata de ajuda, e as voluntárias resultam da validação da necessidade de ajuda; da exploração do significado da necessidade; e da eficácia das ações realizadas para satisfazê-la.

Wiedenbach (1970) defende que enfermagem oferece carinho, presta auxílio, cuida das pessoas, é uma atividade que requer compaixão, habilidade, compreensão, aconselhamento e confiança por parte de quem a exerce. Essa teorista dá uma conotação filosófica e altruísta para a enfermagem, com seus agentes vistos como pessoas zelosas e amorosas.

Levine (1971) vê a enfermagem como um processo dinâmico e intencional, cuja base é a dependência que as pessoas têm de sua relação com o outro, entendendo a ação de enfermagem como uma interação humana em busca de intervenções, para apoiar ou promover o ajustamento do paciente, sendo esse processo ancorado em quatro princípios 
norteadores: conservação de energia; conservação da integridade estrutural; conservação da integridade pessoal; e conservação da integridade social (GEORGE 1993).

King (1981), em sua teoria de consecução de objetivos, analisa como fundamentais para a enfermagem e o cuidado à saúde, os conceitos gerais que assume como pontos chaves: sistema social, saúde, percepção e relações interpessoais, sendo a enfermagem um processo de ação, reação e interação, pelo qual enfermeira e cliente partilham informações sobre suas percepções e, através da comunicação, fixam metas, exploram meios e concordam acerca de sua eficácia para o alcance das metas. O objetivo da enfermeira é auxiliar as pessoas a manterem sua saúde, a interagirem nos papéis que desempenham ao longo da vida.

Rogers, na década de 1970, define a enfermagem, em sua teoria, como uma ciência humanística, dedicada à preocupação piedosa em relação à manutenção e à promoção da saúde, prevenção da doença e cuidado, voltada para a descrição e explicação do ser humano, num todo sinérgico e no desenvolvimento de generalizações hipotéticas e princípios proféticos, inerentes à prática deliberada. Desenvolveu princípios da hemodinâmica, com cinco suposições básicas: o ser humano é um todo unificado que possui integridade individual e que manifesta características que são mais do que a soma das partes e diferentes dela; o indivíduo e o ambiente estão continuamente intercambiando matéria e energia; o processo vital dos seres humanos evolui, irreversível, unidirecional e continuadamente, espacial e temporalmente; padrões identificam os seres humanos e refletem os seus 
diferenciais; e os indivíduos caracterizam-se pela capacidade de abstração e imaginação, linguagem e pensamento, sensação e emoção (ROGERS, 1970).

Há um modelo teórico, o Modelo de Adaptação de Roy, descrito por Roy (1984), caracterizando como elementos essenciais: a pessoa, a meta de enfermagem, as atividades da enfermagem, a saúde e o ambiente, sendo os seres humanos o foco da enfermagem e os sistemas abertos para a interação com o ambiente, compostos de estímulos pessoais internos e externos.

As atividades de enfermagem envolvem o manejo desses estímulos, promovendo reações adaptativas. Para Roy, a meta da enfermagem é promover reações de readequação em relação aos modos adaptativos de função fisiológica, autoconceito, função de papéis e interdependência, utilizando o conhecimento sobre o nível de adaptabilidade da pessoa e os estímulos focais, contextuais e residuais.

Neumam (1989) desenvolve e aprimora uma teoria em que os focos são: o homem, o ambiente e o estresse. Seu modelo de sistema de cuidados à saúde concentra-se na pessoa, grupo ou comunidade como um todo e na reação deles ao estresse. Os estressores podem ser de ordem extrapessoal, interpessoal e intrapessoal. A intervenção de enfermagem vai depender da avaliação minuciosa do significado dos estressores, assim como do conhecimento da capacidade de enfrentamento do indivíduo, sendo que tudo decorrerá da capacitação da enfermeira para executar a contento essa investigação. 
Em Paterson e Zderad (1976) encontramos inter-relação entre os conceitos de seres humanos, saúde, enfermagem e sociedade, sob um ponto de vista de prática humanística. Situam a enfermagem no contexto da filosofia existencial, quando afirmam que a "enfermagem é um diálogo vivido entre a enfermeira e o enfermo", diálogo entendido como o encontro único entre dois seres humanos, sendo que os conhecimentos e informações advindos da análise e reflexão sobre essa relação proporcionam o estímulo do bem-estar e do estar melhor, na atividade cotidiana das coisas e dos homens, além de um conhecimento passível de generalizações. Dão como características essenciais para a enfermagem o cuidado e a relação da enfermeira com a pessoa a ser cuidada, tanto em situações de doença, quanto nas de bem-estar.

A teoria de Watson (1979) preconiza que o foco principal da enfermagem origina-se da combinação da perspectiva humanística dos fatores do cuidado com sólidos conhecimentos científicos, principalmente em Ciências Humanas.

A visão generalizada de mundo e o pensamento analítico desenvolvido são essenciais ao que chama de ciência do cuidado, sintetizada como a promoção da saúde e não a cura de doenças. Um sistema de valores humanistas é utilizado para ancorar a estrutura da sua teoria, com sete suposições básicas: o cuidado pode ser efetivamente demonstrado e praticado unicamente de forma interpessoal; a satisfação de certas necessidades humanas é o resultado dos fatores de cuidado; tanto a promoção da saúde como o crescimento pessoal ou grupal resulta de 
cuidado eficiente; na dimensão do cuidado, a pessoa é vista não somente como se apresenta, mas como pode vir a ser; ambiente de cuidado é aquele que promove o potencial humano, permitindo à pessoa fazer escolhas produtivas para si; a ciência do cuidado é complementar à da cura, pois integra conhecimentos biológicos, fisiológicos e psicológicos do ser humano, para criar e desenvolver saúde e ajuda aos doentes; e a prática do cuidado é a essência da enfermagem.

Além disso, a estrutura de seu modelo também é constituída de dez fatores: a formação de um sistema de valores humanístico-altruístas; a instilação de fé e esperança; a estimulação da sensibilidade interior e ao próximo; o estabelecimento de uma relação de confiança e auxílio; o desenvolvimento e a manifestação assegurada da expressão de sentimentos positivos e negativos; a tomada de decisões pautadas pelo método científico de resolução de problemas; a constância da relação interpessoal no tocante a ensino-aprendizagem; a adequação de ambientes terapêuticos: físico, mental, sociocultural e espiritual; a assistência com satisfação das necessidades humanas; e a permissão de forças existenciais e fenomenológicas.

Em Leopardi (1999) encontramos que Parse criou uma teoria de enfermagem chamada Homem - Vida - Saúde. Dois conceitos paradigmáticos entram em sua definição: 0 da totalidade e o da simultaneidade. No primeiro, o homem é visto como uma combinação de aspectos biopsicológicos e sócio-espirituais e o ambiente com o qual interage, adaptando-se para manter o equilíbrio, em vista dos estímulos 
externos e internos que o cercam. Já o segundo, o da simultaneidade, entende o homem como um ser unitário, em inter-relação contínua e mútua com o ambiente, sua saúde é uma expansão neguentrópica. Há três pressupostos que contam em sua teoria: $\left.1^{0}-\right)$ Homem - Vida - Saúde, em que há sempre a liberdade para as escolhas pessoais que dão sentido às situações, através dos processos intersubjetivos para estabelecer escalas de valores; $2^{\circ}-$ ) Homem - Vida - Saúde, contemplando a inter-relação com o ambiente, participante da criação conjunta de padrões de comportamento; e 30-) Homem - Vida - Saúde, indo o homem além dos limites, transcendendo-os nas diferentes dimensões, das quais ele escolhe as possíveis. São também estabelecidas quatro categorias: 1) A crença de que o homem é mais do que a soma de suas partes sendo diferente delas; 2) O homem evolui reciprocamente com o ambiente; 3) O homem participa na cocriação da saúde pessoal, selecionando significado às situações; e 4) O homem confere a tudo significados, dando-Ihes valores pessoais, que refletem sonhos e esperanças (GEORGE, 1993).

Leininger (1978), nos anos sessenta, setenta e oitenta, através do que denomina Diversidade e Universidade Cultural do Cuidado, definiu um subcampo para o estudo da enfermagem, a teoria transcultural do cuidado.

Em seus pressupostos, fala sobre os elementos comuns de percepção, conhecimento e prática de cuidado nas diferentes culturas, a eles se referindo como elementos de universidade, classificando como diversidade os aspectos de cuidado, que diferem de cultura para cultura. 
Os pontos chaves de sua teoria são os conceitos de cultura (valores, crenças, normas e modos de vida em determinada sociedade, aprendidos, compartilhados e transmitidos, que orientam o pensamento, as decisões e as ações, de maneira geral) e a diversidade cultural do cuidado (a diferenciação entre significados, padrões, valores ou símbolos de cuidado culturalmente apreendidos pelos homens para seu bem-estar, para aperfeiçoar uma condição ou maneira de viver, ou para enfrentar a morte).

Morse (1995) explica que os conceitos podem ser formados pela teoria ou formadores de teoria. A ausência de desenvolvimento conceitual numa área em particular pode influir significativamente em sua evolução. Ë o caso da enfermagem, que convive com algumas lacunas gritantes na base conceitual, envolvendo discrepâncias entre os conceitos ensinados e os utilizados no exercício prático da profissão.

Numa pesquisa de Santo et al. (2000), o conceito de cuidado, para os alunos de graduação, difere do formulado no meio acadêmico. Constatam que, apesar de muito se falar em cuidado/ cuidar, há pouco material escrito sobre o seu significado.

Morse (1991) propõe uma classificação do cuidado nas seguintes categorias:

1) Cuidar como característica pessoal humana

Cuidar é uma parte da natureza humana. É comum e inerente a todas as pessoas. Como característica universal, é geralmente tido como básico e constante e forma o fundamento da sociedade humana. É componente 
essencial e necessário para a sobrevivência humana e a perpetuação da espécie.

Existem diferenças nas manifestações do cuidar entre os grupos humanos, ocasionadas pela variação cultural, e cabe à enfermagem, que tem como agente motivador de sua ação o cuidado, oferecer intervenção congruente com as características culturais do individuo, grupo ou sociedade em que atua (LEININGER, 1978).

2) Cuidar como imperativo moral ou ideal

O ato de cuidar é considerado virtude moral, envolve o bem do paciente e a manutenção da sua dignidade, respeitando-o como ser único.

A enfermeira é vista como agente moral, pois a prática da enfermagem no cuidar utiliza a ética da virtude, já que em sua realidade imediata o toque no corpo é um dos principais atributos do cuidado. Dessa forma, o cuidar leva à intervenção positiva no bem-estar dos outros, simultaneamente refletida no crescimento mental e na espiritualidade da enfermagem (WATSON, 1979).

3) Cuidar como afeto

Cuidar envolve uma emoção, um sentimento de compaixão ou empatia para com o paciente, que motiva a enfermeira a oferecer este cuidado. A intensidade desses sentimentos influi no estado emocional da enfermeira, o que afetará sobremaneira o ato de cuidar, pois a enfermagem trabalha em campos limítrofes entre a vida e a morte.

O ato de cuidar também exige a capacidade de se pôr no lugar do paciente, o que possibilita à enfermeira colocá-lo em primeiro lugar, tanto na 
ação como na mente, através de atos de ajuda e assistência nas atividades da vida diária, que podem ser simples ou complexas.

4) Cuidar como interação interpessoal

A enfermeira e o paciente têm de ser comunicativos, confiar, respeitar e se comprometerem um com o outro. Quando isso ocorre, ambos enriquecem. Morse (1991) considera que a integração de sentimentos e ações é tanta, que a intervenção é qualitativamente diferente daquela num encontro que não envolva o cuidar. Para essa autora, nos pensamentos, ações e sentimentos compartilhados com o cliente, o cuidar estabelece a possibilidade de dar e receber ajuda.

5) Cuidar como intervenção terapêutica

Os teóricos descrevem o cuidar como reconhecimento de qualidades e necessidades individuais. A enfermagem tem de detectar e satisfazer as carências manifestas pelo paciente, sendo enfatizadas então as competências e habilidades na relação do cuidar, que envolvem promover a autonomia e o autocuidado, dar informações, transmitir conhecimentos, ter compaixão, com o intuito sempre de manter e promover a vida.

Após uma jornada de vida na atuação da enfermagem, exercitando o cuidar e o cuidado, uma forma gratificante de brindar a nossa carreira profissional é buscar o entendimento pleno desse imperativo, na esperança de transmitir intelectualmente, através das palavras, aquilo que temos perseguido na prática, rebuscando as entranhas da profissão. 
Assim, esse estudo se volta para os significados e significantes de cuidado, efluídos dos seus atores vislumbrando que estes resultados possibilitem melhora no ensino e na qualidade da assistência.

Para tanto, construímos um instrumento, baseado nos conceitos e classificações de Morse (1991), acima descritos, que possibilite pesquisar as diferenças na concepção do cuidado entre os grupos de alunos de graduação, alunos de pós-graduação, enfermeiros e docentes universitários enfermeiros. 


\section{2 - OBJETIVO}

Conhecer a percepção do cuidar e suas relações entre as concepções do estudante de enfermagem (graduando e especializando), do enfermeiro da assistência e do professor de enfermagem. 


\section{3 - METODOLOGIA}

\subsection{Tipo de Estudo}

Esta pesquisa foi desenvolvida buscando conhecer a percepção do cuidado para alunos, docentes e enfermeiros como entes sociais e emocionais.

A Psicologia como ciência, segundo Braguirolli et al (1994), objetiva compreender em seus estudos a predição e o controle dos fenômenos. Seu desenvolvimento enquanto ciência evoluiu, com diversas disciplinas, sendo a psicometria uma delas, voltada para a medição e avaliação das atitudes comportamentais dos homens.

As atitudes são constitutivas da ação humana, englobando as emoções, os pensamentos e as crenças que delineiam o comportamento. Esse comportamento posiciona o ser humano frente às questões da sociedade em que vive.

A medida escalar, segundo Pasquali (1997), é uma dentre muitas outras formas, que a psicometria pode adotar. Do mesmo modo, o termo escala é usado de diferentes maneiras, sendo um instrumento importante e de grande valia no estudo das atividades, das atitudes e no âmbito da 
personalidade. Busca avaliar os estímulos que expressam um conteúdo psicológico, com correspondência numa grade intervalar - psicológica, em que há uma relação. É instrumento essencial na área das atitudes, definido por Miguel (1983) como um instrumento de auto-avaliação, que mede até que ponto um indivíduo tem sentimentos favoráveis ou desfavoráveis para com uma pessoa, grupo ou instituição social.

Para Richardson (1985), as medidas escalares servem para medir aspectos valorativos e subjetivos das atitudes das pessoas e a variabilidade das mesmas.

São inúmeros os estudos sobre atitudes ou opiniões de um indivíduo. Lima apud Valla (1993) preconiza que provavelmente o conceito de atitude foi o primeiro a dar identidade à psicologia social, colocando-se como a ligação entre a psicologia individual e a sociologia partindo do ponto em que possibilitava identificar a posição de um certo indivíduo frente à sua realidade social.

Para McGuire (1996) opinião é entendida como algo observável e atitude algo inferível, mas não diretamente observável. Ambas, entretanto, têm ligação com os comportamentos.

Smith et al (1960) justificam que as opiniões, como todo comportamento são parte integrante dos dados deduzidos da personalidade, fundamentando uma maneira de ser. Concluem que a opinião de uma pessoa é uma das formas congruentes e constantes do comportamento que a caracteriza. 
Bem (1973) esclarece que opiniões originam-se de um conjunto de valores subjacentes; coletivamente, crenças e opiniões formam a compreensão que o homem tem de si e do mundo ao seu redor sendo que a maioria das suas opiniões é produto da experiência direta.

Encontramos na literatura uma variedade de técnicas e instrumentos que tentam obter medidas de atitudes e opiniões sobre diferentes temas. Pasquali (1996) apresenta vários autores, referenciando os métodos de Thurstone, Likert, Osgood, Guttman, Fishbein e Ajzen.

Para o presente estudo optamos por um instrumento de medida escalar sob o enfoque de Renis Likert, em cujo pressuposto teórico, sustenta que uma atitude (propriedade psicológica) constitui uma disposição para a ação. Segundo Pasquali (1996), este instrumento procura verificar o grau de adesão do indivíduo a uma série de afirmações que sejam expressões de algo favorável ou desfavorável em relação a um objeto psicológico. Acrescenta ainda que esse tipo de escala é construída com a configuração de um conjunto de afirmações sobre o foco de alguma atitude. Essa formulação geralmente é embasada em referencial bibliográfico, vivências e experiências anteriores. Salienta que as afirmações são respondidas numa escala em que o indivíduo tem que dizer se concorda, está em dúvida ou discorda com o que a frase afirma sobre o objeto psicológico. As escalas de respostas variam, sendo as mais comumente utilizadas as de 5 e 7 pontos.

Com base em três grandes vertentes as vantagens desse instrumento são: 
- Teórica: a fundamentação teórica sobre o objeto psicológico para o qual é desenvolvido o instrumento escalar é primordial na clareza do propósito;

- Empírica: define as etapas e técnicas de aplicação do instrumento base para a coleta de informações a fim de que ocorra a validação da qualidade psicométrica do instrumento;

- Analítica: reporta-se aos métodos de análise estatística dos dados, validando o instrumento.

Além do exposto, a construção de escalas, segundo Pasquali (1997), deve seguir alguns requisitos:

1) Critério comportamental: cada item deve possibilitar ao indivíduo uma compreensão clara, de tal forma que o texto reproduza a quotidianidade dos comportamentos do grupo.

2) Critério de desejabilidade e de objetividade: os indivíduos devem atribuir o peso que têm para eles as atitudes, concordando ou discordando se tal comportamento convém ou não para ele.

3) Critério da simplicidade: deve expressar uma única idéia, positiva ou negativa, sem justificativas.

4) Critério de clareza: o item deve ser inteligível, construído com conhecimento de uso lingüístico, com frases curtas, simples e inequívocas.

5) Critério de relevância: pertinência, saturação, unidimensionalidade, correspondência. A semântica deve ser correspondente ao atributo psicológico. 
6) Critério de precisão: o item deve ser estabelecido de modo definido no contínuo atribuído e ser delimitadamente distinto dos demais itens que abrangem o mesmo contínuo.

7) Critério de amplitude: o conjunto dos itens referentes ao mesmo atributo deve cobrir toda a extensão de magnitude do contínuo deste atributo.

8) Critério de equilíbrio: os itens do mesmo contínuo devem cobrir igualmente ou proporcionalmente todos os segmentos do contínuo, devendo haver portanto, itens fracos, moderados e extremos.

9) Critério da variedade: a variação da linguagem e a medição dos termos favoráveis e desfavoráveis devem ser considerados.

10)Critério da modalidade: formular frases que não utilizam expressões extremadas, optando pela forma modal.

11)Critério da tipicidade: formar frases condizentes com o atributo.

12)Critério da credibilidade: o item deve ser formulado sem utilização do linguajar infantil, grotesco ou canhestro.

Nas escalas tipo Likert, ao expressar sua opinião o indivíduo também registra a gradação existente, indo do acordo total até a discordância total.

A validade de um instrumento pode ser definida como a sua capacidade para realmente medir aquilo a que se propôs. Sobre esta posição, há consenso entre os estudiosos do tema.

Para Ragazzi (1976), pode-se validar as escalas tipo Likert, através dos métodos de validação concomitante ou simultânea, ou de validação de 
conteúdo; os resultados irão indicar até que ponto os itens de uma escala representam o universo de crenças, sentimentos ou tendências de ação, com relação ao objeto investigado.

Fazio (1997) faz distinções entre construção e validação, observando que a primeira envolve informação sobre o objeto e a segunda refere-se à informação sobre o julgamento do objeto.

Para Anastasi (1986), o processo de validação de um teste tem início com o detalhamento de definições do construto, oriundos de teoria psicológica, dados de pesquisas anteriores e análises do domínio relevante do comportamento e de observações constantes. Os itens são, então, trabalhados para se moldarem às definições do construto e as análises empíricas passam por seleção, formalizando-se, então, os itens fundamentais.

\subsection{Instrumento de Coleta de Dados}

Construção e avaliação do instrumento

Para atingir o objetivo deste estudo, após um período de densas análises, revisões bibliográficas e reflexões sobre a realidade da profissão, procuramos construir um instrumento, através do qual pudéssemos identificar as atitudes e opiniões dos entrevistados, sobre o tema.

Inicialmente tomamos por base as definições etimológicas de Aurélio (1975) sobre os termos: 
- Atitude: do latim atitudine. Modo de proceder ou agir; comportamento; procedimento; propósito ou maneira de manifestar esse propósito; reação ou maneira de ser, em relação à determinada pessoa, objeto, situações.

- Opinião: do latim opinione: modo de ver, de pensar, de deliberar; parecer; conceito; juízo; reputação; idéia; doutrina; princípio.

A construção da Escala teve origem na análise sistemática de 227 redações de alunos do curso de graduação em enfermagem e de alunos de cursos de especialização em enfermagem, versando sobre o cuidado e seus significados. Através do conteúdo desse material, que representava o imaginário dos alunos, fomos coletando os termos que se apresentavam com maior freqüência. Após esta seleção passamos à verificação conceitual de cada termo. Listamos, finalmente, os que continham alguma definição relacionada a cuidado e/ ou cuidar.

O passo seguinte foi a construção de um grande número de frases afirmativas. Refletirmos sobre elas e dando uma redação uniformizada, elas foram sendo analisadas, refeitas, repensadas e comparadas.

Construímos as afirmativas sobre o cuidado, ancorados nas conceituações de Morse (1991), que as elaborou depois de uma ampla revisão bibliográfica, encontrando-as como afirmações constantes ou implícitas em um grande número de autores. Morse propõe cinco categorias: 1- Cuidar como característica pessoal humana; 2-Cuidar como imperativo moral ou Ideal; 3- Cuidar como afeto; 4-Cuidar como interação interpessoal; e 5- Cuidar como intervenção terapêutica. 
Do montante de afirmativas, após revisão etimológica e semântica, em que nos valemos do aconselhamento e revisão de uma especialista na área, foram selecionadas 50 afirmativas, 10 para cada uma das categorias propostas por Morse.

Foi então formatado o instrumento: uma escala ordinal tipo Likert, de 5 pontos, com a mesma ordem.

Solicitamos a 10 professores (doutores) que participassem do estudo como juízes. Opinaram sobre o instrumento, analisando e julgando o conteúdo de cada afirmativa, quanto aos aspectos de compreensão verbal e pertinência ao tema assim como analisando os aspectos técnicos da sua apresentação. Este procedimento foi indispensável para a validação do instrumento em construção. Os resultados das sugestões dos juízes serviram para nova análise e acertos nas formulações dos ítens.

Após a análise dos juizes, procedemos a nova avaliação das afirmativas, analisando o Índice de Desempenho de cada fator. Foram descartados os que apresentaram porcentagem inferior a $80 \%$ de concordância. Foi considerada como concordância total, em cada afirmativa, a maior soma das porcentagens de duas caselas adjacentes, pois, segundo Pasquali (1999), os itens que não atingem tal concordância apresentam problemas e devem ser desprezados.

Dessa avaliação, extraímos uma nova versão da Escala, com 45 afirmativas, distribuídas pelas 5 categorias, com 9 proposições em cada uma. 
Para Menezes \& Nascimento (1999), a validade de conteúdo é subjetiva, de competência do próprio investigador e nem sempre comporta testes estatísticos.

Com base neste posicionamento, novamente o material foi submetido à apreciação dos mesmos juizes. Foi solicitado que: 1- respondessem o instrumento como sujeitos e 2- apontassem dificuldades, falhas e dúvidas encontradas.

A partir desses resultados, procedemos a uma nova revisão, melhorando a construção de algumas afirmativas, conforme as sugestões apresentadas.

Após essas etapas, demos por concluído esse instrumento denominado Escala de Avaliação do Significado do Cuidar (EASC), apresentada, a seguir, em seu formato original, agrupando 9 questões por categoria, sustentada no referencial de Morse(1991).

Durante a construção e validação da Escala de Avaliação do Significado do Cuidar (EASC), foi incorporada uma folha de rosto contendo os dados de Identificação dos Sujeitos os quais permitiram delinear o perfil da população analisada (alunos, enfermeiros e docentes, Anexos III e IV). Foi anexada também uma carta introdutória, em forma de convite para que participassem do estudo (Anexo I).

A seguir, procedemos ao sorteio em duplo cego para a ordenação das questões, desconectando-as da seqüência por categoria, obtendo-se o instrumento de coleta de dados (Anexo $V$ ) em que a numeração das questões é o resultado do sorteio. 


\section{Escala de Avaliação do Significado do Cuidar - EASC}

O cuidado como característica pessoal humana.

1. Manter as próprias unhas cuidadas é importante.

4. Estou sempre atenta às alterações da minha saúde.

6. Dormir bem todos os dias é fundamental.

7. Minha alimentação diária é equilibrada.

11. A aparência pessoal é importante para o cuidado.

14. Cuidar do próprio corpo é importante.

30. A atividade física faz parte do meu cuidado pessoal.

35. O habito da automedicação é prejudicial.

41. Reservar algum tempo para o próprio lazer é importante.

\section{O cuidado como imperativo moral}

3. Exercer a enfermagem é uma atividade difícil.

10. Cuidar é um ato de compaixão.

15. Cuidar envolve compromisso de um ser humano para com outro.

17. Eu gosto de ser enfermeiro.

22. Cuidar envolve o ideal de servir.

33. O cuidado não tem preço.

36. Quem cuida precisa ter responsabilidade, respeito e honestidade. 
40. A relação de confiança é necessária para o cuidado.

45. Cuidar é sinal de solidariedade.

\section{O cuidado como afeto}

2. O enfermeiro não deve expressar seus sentimentos durante o cuidado.

8. Ao cuidar, o enfermeiro deve ser imparcial.

9. A meiguice precisa estar presente no ato de cuidar.

16. O cuidado envolve afetividade.

21. Cuidar envolve gentileza.

23. Sendo impessoal o enfermeiro cuida melhor.

29. Educação deve fazer parte do cuidado de enfermagem.

39. Cuidar envolve delicadeza.

43. Quem cuida deve estar bem consigo mesmo.

\section{O cuidado como relação interpessoal}

5. $\mathrm{O}$ ato de cuidar exige competência.

18. Cuidar envolve o manejo adequado das situações que se apresentam.

19. O enfermeiro deve ser bem-humorado no desempenho do cuidado.

24. O cuidado exige destreza.

25. O cuidado envolve real interesse de quem cuida.

27. Para cuidar, o enfermeiro deve observar as normas institucionais.

34. Para cuidar, o enfermeiro utiliza procedimentos metódicos. 
37. Ao cuidar o enfermeiro deve valorizar a comunicação.

44. O cuidado envolve perspicácia do enfermeiro.

\section{O cuidado como intervenção terapêutica}

12. Quem cuida deve saber o que o paciente pensa sobre as próprias necessidades.

13. A relação de empatia com o outro é importante no cuidado.

20. O cuidar envolve organização.

26. O cuidado deve ser planejado.

28. A percepção que o cliente tem do enfermeiro interfere no cuidado.

31. O bom cuidado depende da execução correta das técnicas de enfermagem.

32. O código de ética da enfermagem deve ser colocado em prática no cuidar.

38. Conhecer os direitos e os deveres do cidadão para praticar o cuidado é importante.

42. Quem cuida deve considerar os valores do outro. 


\subsection{Procedimentos Éticos}

Este estudo, em sua elaboração, seguiu a Resolução no 196/96 do Conselho Nacional de Saúde (Brasil, 1996), que dispõe sobre pesquisa envolvendo seres humanos.

Dessa forma, consta do instrumento o Consentimento Livre e Esclarecido (Anexo II), no qual é firmado que os procedimentos da pesquisa asseguram a confidencialidade, a privacidade e a imagem dos participantes, assim como a autorização para utilização dos dados para ensino e pesquisa.

Para proceder à coleta de dados foi enviado um ofício aos dirigentes das Instituições de Saúde e de Ensino que congregam os sujeitos alvo deste estudo (Anexo $\mathrm{VI}$ ), que prontamente aquiesceram o pedido.

Outrossim, todos os movimentos acima descritos só ocorreram após a aprovação do projeto pelo Comitê de Ética em Pesquisa da UNIARARAS, credenciado no CONEP, sendo esse parecer parte integrante do estudo (Anexo VII).

\subsection{Campo de Estudo}

A presente pesquisa foi realizada no município de Araras, Estado de São Paulo, geograficamente localizado a Leste do Estado, distando $170 \mathrm{~km}$ da cidade de São Paulo, $76 \mathrm{~km}$ de Campinas, $120 \mathrm{~km}$ de Ribeirão Preto. 
De fácil acesso, a cidade é cortada pela rodovia Anhanguera e margeada pelo entroncamento das rodovias Bandeirantes e Washington Luis.

Fundada em 1865, tem topografia suavemente ondulada, clima quente e seco, com área de $645 \mathrm{~km}^{2}$, perímetro urbano de $302 \mathrm{~km}^{2}$, altitude de $611 \mathrm{~m}$ e população de 104.196 habitantes, segundo o Censo 2000 do IBGE.

Culturalmente a cidade é marcada por fatos históricos que a coloca em situação exponencial, como a Emancipação da Escravatura antes da Lei Áurea, em abril de 1888; primeira Festa das Árvores da América Latina, em 7 de junho de 1902; Banda Campeã do Brasil 1977 (Corporação Musical Municipal "Maestro Francisco Paulo Russo"); Município de Maior Progresso no Brasil (IBAM), 1955 e 1956; Município Agrícola Modelo do Brasil (INDA), 1967 e 1968; Município Modelo do Estado de São Paulo (INDA), 1967; Município de Maior Desenvolvimento do Brasil (Dirigente Municipal - Grupo Visão), 1981, 1985, 1986, 1987, 1989, 1991; Cidade do Ano em Segurança no Trânsito (Prêmio Volvo), 1993.

Conta a cidade com uma infra-estrutura de saneamento básico excelente, com 100\% de água tratada e fluoretada, 100\% de esgoto tratado, 95\% de pavimentação, 97\% de iluminação, 100\% de coleta de lixo domiciliar.

Na área cultural conta com espaços específicos, como a Casa da Cultura, Ciência e Tecnologia, prédio que data de 1896, construído pelo arquiteto Dr. Victor Dubrugas; o Teatro Estadual, com capacidade para 466 
lugares e projetado pelo arquiteto Oscar Neimayer; a Biblioteca Municipal, instalada em 1947, que funciona em moderno prédio próprio, com um acervo de 43.000 volumes.

Na área da saúde, a cidade conta com três Hospitais Gerais e 1 hospital psiquiátrico, a saber:

1-A Irmandade da Santa Casa de Misericórdia de Araras, mantenedora do Hospital São Luiz e da Maternidade Condessa Marina Crespi, com um total de 303 leitos distribuídos em: Anestesiologia, Angiologia, Cardiologia, Cirurgia Cardiovascular, Clínica Médica, Clínica Cirurgia Geral, Cirurgia Pediátrica, Cirurgia Plástica, Cirurgia Oncológica, Cirurgia Vascular, Dermatologia, Endocrinologia, Gastroenterologia, Gastropediatria, Ginecologia, Hematologia, Hemoterapia, Nefrologia, Neurologia, Neurocirurgia, Neuropediatria, Obstetrícia, Oftalmologia, Ortopedia e Traumatologia, Otorrinolaringologia, Pediatria, Pneumologia, Psiquiatria, Urologia, Hemodinâmica.

Conta também com Centro Cirúrgico e Centro Obstétrico, funcionando com alta tecnologia, Central de Esterilização, Centro de Terapia Intensiva com Unidades Adulto, Infantil e Neonatal, além de bem montados serviços de apoio, bem como os de Diagnóstico e Terapêutica. Mantém serviços de Hemodiálise, Oncologia, e também Quimioterapia.

Todas essas unidades são utilizadas para os estágios supervisionados de graduação, pós-graduação e para programas assistenciais dos diversos cursos da Uniararas. $\mathrm{O}$ desenvolvimento desses trabalhos ocorre em total conjunção com as atividades e 
profissionais da Santa Casa, em número de 731, dentre eles 23 enfermeiros, 353 profissionais da equipe de enfermagem e 125 médicos, favorecendo o intercâmbio de experiências.

2- O Hospital UNIMED, com 50 leitos instalado em um complexo arquitetônico moderno e arrojado, dentro dos mais avançados preceitos tecnológicos, contemplam as diversas especialidades da medicina. É também um dos campos de atividades práticas da Uniararas. A equipe de enfermagem conta com sete enfermeiros.

3- Pró-Saúde, hospital de uma associação de empresas, com 20 leitos. É dotado de infra-estrutura básica hospitalar, para atendimentos de baixa complexidade. Tem em seu quadro funcional cinco enfermeiros.

4-. Clínica de Acompanhamento Psiquiátrico e Geriátrico Antonio Luiz Sayão, instituição filantrópica com 800 leitos, sendo 600 deles destinados a pacientes portadores de transtornos mentais, 50 ao atendimento geriátrico e 150 à assistência de crianças portadoras de múltiplas deficiências congênitas físicas e mentais. A clínica tem um corpo funcional de 624 funcionários e dentre eles, 18 enfermeiros.

Na área preventiva primária e secundária, a cidade é servida por 14 Unidades Básicas de Saúde, cinco Programas de Saúde da Família, dois Programas de Agentes Comunitários em Saúde, um Centro Odontológico, um Serviço de Pronto Atendimento, um Ambulatório de Saúde Mental, um Centro de Atenção à Saúde da Mulher e 1 Centro de Saúde.

O Município conta ainda com Centros de Iniciação ao Trabalho (CIT) e um Centro de Apoio Integral à Criança e ao Adolescente, além de 
inúmeras Organizações não Governamentais envolvidas com as questões de saúde, educação e promoção social.

Na área educacional básica o Município conta com quatro creches destinadas ao atendimento de crianças de 3 meses a 3 anos; 26 escolas de educação infantil; 30 escolas de $1^{\circ}$ Grau na zona urbana e 30 escolas de $1^{\circ}$ Grau na zona rural; 8 escolas de $1^{\circ}$ e $2^{\circ}$ Graus; 3 cursos pré - vestibulares; 1 escola para deficientes mentais e 1 escola para deficientes auditivos e visuais.

Na área técnica profissionalizante há 3 cursos de Contabilidade, 1 de Açúcar e Álcool, 2 de Magistério, 1 de Nutrição, 1 de Eletrotécnica, 1 de Mecânica e 3 de Enfermagem.

Através do SENAI cursos médios profissionalizantes são ministrados, com os cursos técnicos de nível médio de Desenho Mecânico, Ajustador Mecânico, Torneiro Mecânico, Eletricista Instalador, Eletricista Enrolador e Eletricista de Comando Elétrico.

O ensino universitário é contemplado com três sólidas instituições: a Faculdade de Ciências e Letras de Araras, com os cursos de Letras, Educação Artística, Geografia, Pedagogia, Direito e Administração; a Universidade Federal de São Carlos, com o curso de Engenharia Agronômica; e a Fundação Hermínio Ometto, mantenedora da UNIARARAS, com os cursos de Biomédicas, Biologia, Enfermagem, Farmácia e Bioquímica, Farmácia Industrial, Odontologia, Psicologia, Fisioterapia e Educação Física, Instituto Normal Superior, Fonoaudiologia e Tecnólogos 
em Biossegurança e Vigilância Sanitária, Gestão Ambiental, Estética e Cosmetologia, Ecologia e Paisagismo e Ecoturismo.

O Município conta ainda com Centros de Iniciação ao Trabalho (CIT) e um Centro de Apoio Integral à Criança e ao Adolescente.

Com 30 anos de existência, a UNIARARAS é uma Fundação Educacional sem fins lucrativos. Conta com um corpo docente de 156 professores e com número total de 3200 alunos na sede e mais de 6000 fora dela.

O Curso de Enfermagem, o segundo na ordem de instalação, teve seu funcionamento autorizado pelo Parecer CEE 1561/79, Decreto Federal 84.536/80, em 10 de março de 1980, e o seu reconhecimento através do Parecer CEE 1149/83, Port. Min. 377/83, de 27 de julho de 1983. Conta hoje, além da Graduação, com cursos de especialização lato-sensu, há quatro anos, nas áreas de Cardiologia e UTI, Saúde da Família e Home Care, Saúde Mental, Atendimento Pré-Hospitalar e Sistematização da Assistência.

A Lei n. ${ }^{\circ}$ 9394, de 20 de dezembro de 1996, que estabelece as diretrizes e bases da educação nacional, confere parâmetros importantes para o ensino superior.

A reflexão sobre o ensino superior atual deve se orientar para as possibilidades abertas à transformação do sistema e para apresentar propostas concretas para elaboração das medidas que poderão ser adotadas. 
Com o progresso do conhecimento científico, alterou-se a própria concepção de educação superior. Não se trata mais de transmitir um saber constituído, que poderá ser rapidamente ultrapassado, mas de fornecer o domínio dos instrumentos que produzem novos conhecimentos. O exercício de toda a ocupação intelectual e científica passou a exigir constante atualização.

Assim, a pesquisa deve permear o ensino e devem ser desenvolvidos programas de pós-graduação em nível de "latu e strito senso".

Ao planificar o ensino na Faculdade de Enfermagem de Araras, levamos em consideração tanto o conteúdo como o método: aprendizagem centrada no problema, com permanente contato com a realidade, através de ensino clínico e estágios supervisionados para consolidação de uma experiência acadêmica que irá influir na formação profissional e ampliar as oportunidades de crescimento, amadurecimento e responsabilidade dos envolvidos no processo ensino - aprendizagem.

O curso de Graduação em Enfermagem, com Habilitação em Bacharel tem a duração de quatro anos (ou oito semestres), com carga horária de 4114 horas, possibilitando, ainda, a habilitação em Licenciatura, o que acrescenta uma carga horária de 572 horas. É ministrado em período integral e conta com 120 vagas.

O curso tem seu eixo baseado em conhecimentos hierarquizados em níveis de complexidade partindo de conceitos básicos e universais de saúde para construtos específicos e referenciais de saúde e de doença, para a ação de Enfermagem. 
Nos módulos básicos, o aluno recebe formação em Ciências Biológicas, Humanas e Sociais, com os princípios elementares da formação profissional, que promovem a integração e o desenvolvimento na área da saúde e na profissão de Enfermeiro.

$\mathrm{Na}$ formação específica, são oferecidas ao aluno experiências de ensino e aprendizagem organizados de modo escalonado e seqüencial (cuidados primários, secundários e terciários), capacitando-o para desenvolver a sistematização da assistência de Enfermagem nas diversas áreas relacionadas à saúde - doença.

Completando a formação para Graduação, o conhecimento administrativo pretende capacitar o aluno para organizar e gerenciar unidades de saúde hospitalar e de serviços de saúde pública.

É dada distinção ao Enfermeiro apto a atuar tanto nas áreas técnico científicas, como nas ético - político - sócio - educativas. Prepara o seu graduando para que atue em todas as esferas básicas da prática de Enfermagem, identificando necessidades vitais de âmbitos individual e coletivo, dentro do pressuposto nos moldes clínico e epidemiológico; intervenha em todo o complexo processo saúde - doença, dando atendimento integral de qualidade ao ser humano, considerando também família e comunidade; promova sintonia entre a demanda de clientes e as habilidades profissionais dos membros da equipe da Enfermagem, assim como entre as ações de Enfermagem e as multiprofissionais; gerencie a ação da Enfermagem em todas as suas especialidades de atendimento, reconhecendo o processo de avaliação e o impacto dos passos tomados; 
crie e implemente programas de aperfeiçoamento contínuo dos profissionais de Enfermagem, participando da formação de recursos humanos também nas outras áreas com ligações com a Enfermagem; planeje e efetive programas de saúde conforme a realidade de cada grupo social; envolva-se diretamente com pesquisas para melhor prática da profissão; honre os códigos éticos, políticos e normativos da Enfermagem; adquira desenvoltura em comportamentos de caráter profissional e social; atue efetivamente na dinâmica do trabalho institucional; e se engaje em todos os movimentos em prol da qualificação da saúde e do bem-estar da humanidade.

A Faculdade de Enfermagem ministra um ensino integrado, privilegiando a busca do conhecimento e a formação de um profissional generalista e consciente, na esfera individual e coletiva, junto ao cliente e à comunidade.

O corpo docente conta com 49 profissionais, sendo 24 enfermeiros.

\subsection{Os Sujeitos do Estudo}

A população deste estudo foi constituída pelos elementos abaixo discriminados, conforme apresentado na Tabela 1:

1) Alunos graduandos de enfermagem, pertencentes ao último semestre do curso de graduação em Enfermagem da UNIARARAS.

2) Alunos dos cursos de especialização "latu senso" em Enfermagem, do Centro Universitário Hermínio Ometto (Cardiologia e UTI, Saúde da Família, Obstetrícia e Sistematização da Assistência). 
3) Enfermeiros de algumas instituições de Saúde do Município (Santa Casa de Misericórdia de Araras, Hospital UNIMED e Clínica de Acompanhamento Psiquiátrico Antonio Luiz Sayão).

4) Professores/ enfermeiros da UNIARARAS

Não participaram do estudo as outras instituições de saúde com quadro funcional de enfermeiros, pelo fato de haver, entre os sujeitos estudados, um número significativo deles trabalhando em dois locais, sendo um deles uma dessas instituições.

A amostra foi definida segundo o critério de presença no local da coleta, no dia da aplicação da Escala de Avaliação dos Significados do Cuidado, para cada um dos grupos de sujeito.

Tabela 1- Distribuição dos sujeitos participantes da pesquisa, segundo sua vinculação institucional.

\begin{tabular}{lllcc}
\hline Procedência Institucional dos Sujeitos & População & amostra & $\%$ \\
\hline $\begin{array}{l}\text { Alunos graduandos de enfermagem, da } \\
\text { Uniararas }\end{array}$ & 65 & 21 & 32,3 \\
$\begin{array}{l}\text { Alunos cursos de especialização em } \\
\text { enfermagem, da Uniararas }\end{array}$ & 120 & 99 & 82,5 \\
Enfermeiros assistenciais & 48 & 29 & 60,4 \\
Professores lenfermeiros da Uniararas & 24 & 22 & 91,6 \\
\hline Totais & 257 & 171 & 66,5 \\
\hline
\end{tabular}




\subsection{Procedimentos de Coleta dos Dados}

A coleta dos dados transcorreu durante o mês de setembro de 2002.

O instrumento foi aplicado pela pesquisadora, que explicava aos sujeitos presentes naquele dia e hora, os objetivos do trabalho. Cada sujeito lia e respondia seu instrumento, individualmente. A pesquisadora permanecia à disposição dos sujeitos, durante o período de preenchimento, para possíveis esclarecimentos.

A coleta foi efetuada segundo os preceitos éticos, garantindo a liberdade de participação e a de expressão, bem como o anonimato. Todos assinaram o Termo de Consentimento, hoje arquivados como documentos.

$\mathrm{Na}$ população de alunos de graduação e da pós-graduação, a aplicação seguiu o procedimento descrito, ou seja, a pesquisadora aplicou o instrumento nos dias em que aconteciam as aulas do quarto ano e das diversas especializações. Participaram os alunos presentes.

Aos professores, o mesmo foi aplicado em 2 reuniões agendadas, quando as explicações precederam o consentimento e a coleta.

Nos hospitais, as visitas foram agendadas em cada turno de trabalho e em um determinado dia para cada instituição, escolhido aleatoriamente, ficando sempre a pesquisadora à disposição dos sujeitos para os esclarecimentos que se fizessem necessários. 


\subsection{Procedimentos de Análise dos Dados}

Os dados registrados foram tratados e analisados, digitados e processados através de programas informatizados, específicos para o estudo, e receberam tratamento estatístico para possibilitar o exame da existência ou não de diferenças entre os grupos e as categorias.

Os 171 questionários foram numerados por grupos de sujeitos, na seguinte seqüência:

0 a $21=$ alunos graduandos de enfermagem

22 a 120= alunos de especialização em enfermagem

121 a 149= enfermeiros da assistência

150 a $171=$ professores enfermeiros

As respostas de cada sujeito por grupo foram registradas através de um software adequado para manipulação dos dados em forma de índice de adesão de fatores (SPA) e em forma de planilha (Excel).

Foram então somados os valores das freqüências absolutas e percentuais das respostas de cada sujeito, por grupo e por categoria, e calculadas as suas medianas.

\section{$\underline{\text { Testes Estatísticos }}$}

Foram empregadas provas não paramétricas, para verificar se eram ou não significantes as diferenças entre os 4 grupos. Para todos os testes, admitiu-se como probabilidade de ocorrência o erro de primeira espécie (erro tipo I) o valor de alfa $=5 \%$. 
Foi empregada a prova de Kruskal-Wallis para verificar os escores de cada grupo, se diferiam ou não dos demais. Seguindo as indicações de SIEGEL (1975, p.209-218) calcularam-se os valores da estatística $\mathrm{H}$, comparando-os com o valor crítico do Qui-quadrado, com dois graus de liberdade $(5,99)$.

\section{Análise qualitativa}

A análise qualitativa privilegiou a comparação dos dados, amparada no arcabouço teórico deste estudo.

As respostas dos sujeitos em cada item permitiram comparações qualitativas dos resultados. Os dados que se destacaram foram discutidos e amparados pela literatura pertinente. 


\section{IV- APRESENTAÇÃO E ANÁLISE DOS RESULTADOS}

\section{1 - Perfil da amostra}

A amostra deste estudo foi constituída por 171 sujeitos, 21 alunos de graduação, 99 alunos de pós-graduação, 29 enfermeiros da assistência e 22 professores enfermeiros.

Os dados deste perfil mostram diferenças interessantes entre os grupos.

No item idade, observa-se para o grupo de graduandos uma média de 29 anos, o que podemos considerar bem acima da média de idade dos concluintes de cursos universitários, pois entre os graduandos que participaram do Exame Nacional de Cursos 2002, a faixa etária de até 24 anos é a que concentra o maior percentual, com $49,7 \%$ do total geral (INEP 2003). Para os alunos especializandos, a média da idade ficou em 31,8 anos. Entre os enfermeiros da assistência, a idade variou de 22 a 52 anos, perfazendo uma média de 34 anos de vida. A idade média dos professores é de 35 anos, caracterizando uma população jovem, pelas exigências da função, inclusive a titulação. 
Quanto ao sexo, confirma-se a representação maciça feminina entre os professores enfermeiros e alunos da pós-graduação, com 90,9\% e 93,9\% respectivamente. Os enfermeiros na assistência estão representados por $79,3 \%$ do sexo feminino e $20,7 \%$ do masculino, tendência esta que se repete entre os alunos da graduação, por $76,2 \%$ do feminino e $23,8 \%$ do masculino.

O percentual nacional, quando se analisa o total de graduandos em 2002 , independentemente do curso de origem, é representado por $66 \%$ de população feminina, sendo que a enfermagem atinge uma presença significativamente maior de mulheres, com 89\% (INEP, 2003).

Analisando o núcleo familiar, constatamos que $57,1 \%$ dos alunos de graduação e 58,6\% dos alunos de pós-graduação são solteiros, dados próximo ao da percentagem do total nacional de graduandos, que é de 63\%, conforme os resultados do INEP (2003) sendo $73 \%$ o total nacional na enfermagem.

Observa-se, nas estatísticas, um diferencial entre o percentual de alunos solteiros na rede pública, com $83,4 \%$ de representação, contra $67,8 \%$ na escola privada. Em relação aos enfermeiros da assistência e professores enfermeiros, os percentuais dos casados são destacados, 55,2\% e 77,3\%, respectivamente.

Os separados apresentaram um percentual de 6,1\% e 6,9\% para alunos da pós-graduação e enfermeiros da assistência, resultado pouco diferente do resultado do censo populacional nacional 2000 (IBGE, 2003) qual apresenta a porcentagem de 3,7\%. Se tomarmos como base a 
estatística referente ao total nacional de estudantes graduandos, veremos um percentual de $4,11 \%$ de sujeitos separados, sendo que a média geral dos estudantes de enfermagem neste estado civil é de $5,4 \%$ para os que estudam na rede privada e 2,7\% para os matriculados na rede pública.

Quanto aos viúvos, os dados da população nacional indicaram 4,6\%, contrapondo-se a $2 \%$ de alunos da pós-graduação e 3,5\% dentre os enfermeiros da assistência, o que se explica pela faixa etária em que se encontram os sujeitos.

No item procedência observa-se 23,8 \% de Araras e $76 \%$ de cidades localizadas em um raio de no máximo 90 km, caracterizando uma população regionalizada e eminentemente urbana, sendo que $47,6 \%$ residem em Araras. Dentre os alunos da pós-graduação 18,2\% são de Araras e $80,8 \%$ de outras cidades e regiões.

Quanto aos enfermeiros da assistência observa-se que a quase totalidade $(96,5 \%)$ reside na cidade de Araras e somente 1 enfermeiro mora em cidades vizinhas. Entre os professores, observa-se que metade do corpo docente de enfermeiros $(54,5 \%)$ reside no município e a outra metade (45,5\%) em cidades próximas.

A média nacional dos graduandos que residem com as famílias é de $60,6 \%$. O dado nacional para os graduandos de enfermagem é de $61,6 \%$, com um diferencial de 56,8\%. Na média nacional, $60,6 \%$ residem com os pais e/ou parentes e 7,2\%, com amigos. 
Quando se observam os dados da enfermagem nacional, a média dos que moravam com a família é de $61,3 \%$ com um diferencial de 56,8\% entre os que estudam na rede pública e de $59,9 \%$ na rede privada.

Dentre os alunos de graduação que participaram do estudo, 47,6\% moram com a família; 23,8\%, com amigos e 19,1\%, sozinhos. Diferentes são os dados dos alunos de especialização, dos enfermeiros da assistência e dos professores, com respectivamente $56,9 \%, 89,7 \%$ e 90,9\% morando com os familiares. Observe-se que a fase de residir só ou com amigos é característica da fase universitária, diminuindo durante a busca de especializações e não sendo significativa na fase de estabilidade entre os que já estão no mercado de trabalho e definidos profissionalmente.

Os meios de transporte mais usados pelos alunos de graduação do estudo pontuam-se em 47,6\% com veículo próprio e 42,9\% com transporte coletivo, sendo que o transporte público só é utilizado por 9,5\% dos alunos, números esses bem próximos das médias nacionais (37,4\% e 44,8\%).

Se compararmos esses números com as médias nacionais da enfermagem, veremos que 19,7\% têm veículo próprio e 61,8\% usam o transporte público e somente $4,36 \%$ usam transporte coletivo contratado com amigos.

Olhando as diferenças entre os alunos de enfermagem da rede pública e da rede privada, verificam-se $16,36 \%$ e $22,9 \%$ com transporte próprio e $54,1 \%$ e 59,9\% com transporte público. Para os outros grupos de estudo, veículo próprio é utilizado em sua quase totalidade. 
Entre os alunos da graduação, está equilibrado o percentual dos que trabalham durante o curso e dos que não o fazem, com 47,6\% e 52,4\%, respectivamente. A média nacional geral dos que trabalharam durante seus cursos de graduação é de $71,7 \%$ e a média nacional da enfermagem é de $40,2 \%$

A média de anos de trabalho na enfermagem é de 8,6 para os alunos da pós-graduação, 11,5 para os enfermeiros da assistência e 14,8 para os professores enfermeiros.

O tempo de formados dos alunos da pós-graduação variou de 1 a 23 anos, sendo 7,1\%, no período de 1980 a 1985; 10,1\%, de 1986 a 1990; 13,1\%, de 1991 a 95; 52,5\%, de 1996 a 2000 e 17,2\% formados em 2001. Esse demonstrativo ilustra a tendência do mercado em valorizar a continuidade dos estudos, ou seja, 69,7\%.

Em relação às áreas de atuação, é interessante salientar que 95,4\% dos professores já trabalharam também na assistência, e dentre os alunos da pós-graduação e enfermeiros da assistência, 48,5\% e 20,7\%, respectivamente, dedicam-se também ao ensino.

Quanto à continuidade dos estudos, observa-se que, dentre os alunos da pós-graduação, 21,2\% já tinham freqüentado outra especialização e 2,1\% estavam em cursos de mestrado.

Dentre os enfermeiros da assistência, 51,7\% tinham uma especialização concluída e 24,2\% a estavam cursando, assim como 3,45\% estavam matriculados em programas de mestrado. 
Em relação aos professores/enfermeiros, verifica-se a presença de 68,2\% com especialização e 54,55\% com mestrado concluído, assim como 18,2\% freqüentando cursos de mestrado e 9,1\%, de doutorado.

O número médio de pessoas por família é bastante semelhante entre os 4 grupos, variando de 3,14 para os professores/enfermeiros a 3,59 para os enfermeiros da assistência.

Esses índices correspondem à média nacional que, segundo o censo nacional de 2000 (IBGE, 2003), é de 3,5 componentes por família.

Quanto à média de renda familiar, tomando por base o salário mínimo, vigente à época da coleta de dados ( $R$ \$ 210,00), encontram-se respectivamente, as médias de $8,17,11$ e 33 salários mínimos para os grupos dos alunos da graduação, alunos da pós-graduação, enfermeiros da assistência e professores enfermeiros, respectivamente.

No censo escolar do INEP, em 2002, temos que $42 \%$ do total nacional dos graduandos viviam em famílias com faixa de renda familiar variando de 3 a 10 salários mínimos, sendo que para o grupo da enfermagem essa condição ocorreu em 55,3\% dos casos.

Pelos dados do IBGE, 50,1\% da população acima dos 10 anos têm rendimento médio de até dois salários mínimos; 31,8\%, de 2 a 10 salários mínimos; 3,5\%, de 10 a 20 salários mínimos e somente 1,6\%, acima de 20.

Considerando esses parâmetros nacionais, verifica-se que a renda média familiar da população do estudo variou de 02 salários mínimos para o grupo de alunos da graduação, 5 para os alunos da PG, 3,5 para os 
enfermeiros da assistência e, finalizando, 10 para os professores enfermeiros.

Essa análise é corroborada pelos dados do IBGE (2003) e pelo DIEESE (2002) que mostram a progressão do nível de rendimento da população economicamente ocupada, segundo os anos de estudo, que é inversamente proporcional, ou seja, quanto mais anos de instrução tem a pessoa, maior é o seu rendimento.

\section{2- Análise estatística da Escala}

As respostas de todos os sujeitos às 45 afirmativas da Escala (EASC) foram disponibilizadas através da impressão dos registros na planilha Excel.

$\mathrm{Na}$ análise estatística psicométrica quantitativa comparou-se os quatro grupos independentes, sendo considerado o grupo um, os alunos da graduação em enfermagem, o grupo dois, os alunos da especialização em enfermagem, o grupo três enfermeiros da assistência e grupo quatro os professores enfermeiros, totalizando um $\mathrm{n}$ de 171 sujeitos.

Testou-se, dentro de cada grupo, a possibilidade de haver diferenças entre as categorias, sendo aplicada a prova não paramétrica de KruskalWallis, que segundo Siegel (1975), costuma ser a prova não paramétrica que demonstra maior eficiência na comparação de amostras independentes. 
Admitimos a probabilidade de ocorrência de erro tipo I o valor de alfa $=5 \%$ e calculamos os valores da estatística $\mathrm{H}$, comparando-os com o valor crítico do Qui-quadrado com dois graus de liberdade.

Verificamos na distribuição da mediana das 5 categorias com os 4 grupos de sujeitos que ocorreu, na categoria de Significados do Cuidar como Imperativo Moral uma variação significativa de um grupo para outro, mais acentuada no grupo 1 (alunos da graduação), com um nível de significância de 0,43. Podemos pensar que essa diferença justifica-se pelo fato de o aluno graduando estar imbuído de ideais e esperanças em relação à sua entrada no mercado de trabalho bem como expectativas de bem aplicar os conceitos acadêmicos na lida profissional.

Nos outros grupos não foram encontrados resultados com diferenças significativas.

Quando analisado o conjunto das categorias, verificamos que os grupos no todo são diferentes, com um nível de significância de 0,002.

Quando comparados os resultados totais grupo a grupo, encontramse semelhanças entre o grupo 1 e o grupo 4 e entre o grupo 2 e o grupo 3 . Verifica-se no entanto, resultados com uma grande diferença de quase o dobro do nível de significância entre os dois conjuntos de grupos.

Esses dados podem ser visualizados nas tabelas 2 e 3 apresentadas a seguir: 
Tabela 2- Distribuição das medianas das respostas dos grupos de sujeitos, nas 5 categorias de concepção de cuidado na enfermagem.

\begin{tabular}{|c|c|c|c|}
\hline CATEGORIAS & GRUPOS DE SUJEITOS & AMOSTRA & RESULTADOS \\
\hline \multirow{5}{*}{ PESSOAL HUMANA } & 1 & 21 & 86,10 \\
\hline & 2 & 99 & 81,37 \\
\hline & 3 & 29 & 83,14 \\
\hline & 4 & 22 & 110,50 \\
\hline & TOTAL & 171 & \\
\hline \multirow{5}{*}{ IMPERATIVO MORAL } & 1 & 21 & 112,02 \\
\hline & 2 & 99 & 85,12 \\
\hline & 3 & 29 & 72,60 \\
\hline & 4 & 22 & 82,77 \\
\hline & TOTAL & 171 & \\
\hline \multirow{5}{*}{ AFETO } & 1 & 21 & 96,24 \\
\hline & 2 & 99 & 82,70 \\
\hline & 3 & 29 & 75,31 \\
\hline & 4 & 22 & 105,16 \\
\hline & TOTAL & 171 & \\
\hline \multirow{5}{*}{$\begin{array}{c}\text { RELAÇÃO } \\
\text { INTERPSSSOAL }\end{array}$} & 1 & 21 & 84,12 \\
\hline & 2 & 99 & 87,59 \\
\hline & 3 & 29 & 70,90 \\
\hline & 4 & 22 & 100,57 \\
\hline & TOTAL & 171 & \\
\hline \multirow{5}{*}{$\begin{array}{l}\text { INTERVENÇÃO } \\
\text { TERAPEUTICA }\end{array}$} & 1 & 21 & 95,67 \\
\hline & 2 & 99 & 83,86 \\
\hline & 3 & 29 & 77,03 \\
\hline & 4 & 22 & 98,20 \\
\hline & TOTAL & 171 & \\
\hline \multirow{5}{*}{ TOTAIS } & 1 & 21 & 106,31 \\
\hline & 2 & 99 & 81,52 \\
\hline & 3 & 29 & 66,59 \\
\hline & 4 & 22 & 112,39 \\
\hline & TOTAL & 171 & \\
\hline
\end{tabular}

Teste KrusKal-Wallis

\begin{tabular}{|c|}
\hline \\
\hline $\begin{array}{l}\text { 1- Alunos da Graduação } \\
\text { 2- Alunos da Especialização } \\
\text { 3- Enfermeiros Assistênciais } \\
\text { 4- Professores Enfermeiros }\end{array}$ \\
\hline
\end{tabular}


Tabela 3 - Apresentação dos resultados do Quiquadrado e nível de significância de respostas dos sujeitos nas 5 categorias de concepção de cuidado.

\begin{tabular}{|c|c|c|c|c|c|c|}
\hline Categorias & $\begin{array}{l}\text { Pessoal } \\
\text { humana }\end{array}$ & $\frac{\text { Imperativo }}{\text { moral }}$ & Afeto & $\begin{array}{c}\text { Relação } \\
\text { interpessoal }\end{array}$ & $\begin{array}{l}\text { Intervencão } \\
\text { terapeutica }\end{array}$ & Total \\
\hline Quiquadrado & 6,402 & 8,134 & 6,035 & 4,777 & 3,303 & 15,07 \\
\hline $\begin{array}{l}\text { Nível de } \\
\text { significância }\end{array}$ & 0,094 & 0,043 & 0,110 & 0,189 & 0,347 & 0,002 \\
\hline
\end{tabular}

\section{3 - Análise Qualitativa dos Resultados}

\section{A - Diferença entre os grupos nas percepções de significado do cuidado por categoria.}

Segundo Morse et al (1990), não houve consenso, nos resultados de suas pesquisas, no que tange às questões do cuidado. As autoras após delinearem e compararem várias definições de cuidar de acordo com 5 principais conceitualizações do cuidar (cuidar como característica humana, como imperativo moral, como afeto, como uma interação interpessoal e como uma intervenção) identificaram os pontos comuns, pontos fortes, pontos fracos e suas implicações para a prática de enfermagem, chegando à conclusão de que cuidar não está totalmente desenvolvido como conceito, não é claramente explicado e freqüentemente falta relevância para a ação de enfermagem. 
A conduta humana, segundo Bleger (1989) é uma unidade que tem tríplice manifestação fenomênica, ou seja, três áreas coexistentes embora o predomínio em algumas delas nos permita classificar a conduta como mental, corporal ou do mundo externo.

Toda conduta depende de prévia ordenação ou existência na mente, portanto, toda conduta tem a mente como fonte das suas manifestações.

Toda conduta do ser humano tem um sentido. O sentido da conduta como subjetivo é inacessível ele precisa de alguma forma ser expresso.

O sentido da conduta radica no contexto do qual ela emerge, ou seja, no conjunto de relações estabelecidas.

O significado é um aspecto cultural e pode ser materialmente registrado, descrito e definido, trazendo consigo um valor objetivo.

$\mathrm{Na}$ análise dos resultados obtidos com a aplicação da Escala de Significados do Cuidar (EASC) na presente pesquisa, verifica-se que existem algumas diferenças significativas entre os grupos, nas suas percepções de significado, em relação às categorias propostas.

\section{1- O cuidado como característica pessoal humana}

Quando analisamos os resultados dos significados do cuidar como característica pessoal humana constatamos que as afirmativas relativas à aparência do prestador do cuidado tiveram um índice de desempenho de concordância ótimo, com acima de $80 \%$ de adesão. Em contrapartida, nas 
questões em que era exigida a internalização perceptiva do cuidado consigo, pudemos observar que os índices de concordância não são otimizados, mostrando que a atenção com a própria saúde, o conforto, a própria alimentação, assim como a atividade física, não são tão priorizados como significantes do cuidado.

Gráfico 1- Distribuição das respostas dos sujeitos às 9 afirmativas relativas ao conceito do significado do cuidar como característica humana

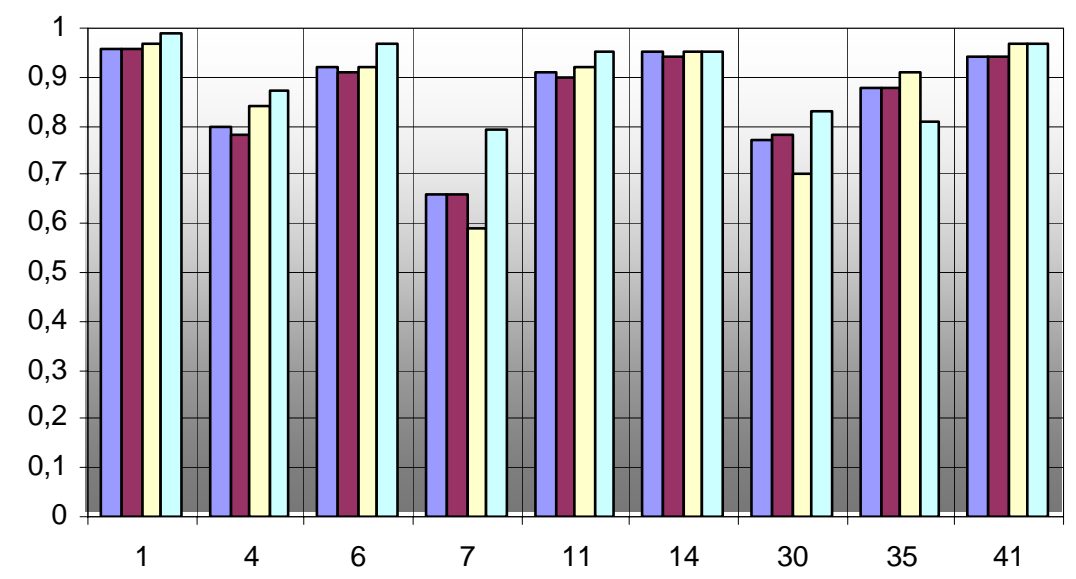

\begin{tabular}{ccccc}
\hline AFIRMATIVAS & $\begin{array}{c}\text { ALUNOS DA } \\
\text { GRADUAÇÃO }\end{array}$ & $\begin{array}{c}\text { ALUNOS DA } \\
\text { ESPECIALIZAÇÃO }\end{array}$ & ENFERMEIROS & $\begin{array}{c}\text { PROFESSORES } \\
\text { ENFERMEIROS }\end{array}$ \\
\hline 1 & 0,96 & 0,96 & 0,97 & 0,99 \\
4 & 0,80 & 0,78 & 0,84 & 0,87 \\
6 & 0,92 & 0,91 & 0,92 & 0,97 \\
7 & 0,66 & 0,66 & 0,59 & 0,79 \\
11 & 0,91 & 0,90 & 0,92 & 0,95 \\
14 & 0,95 & 0,94 & 0,95 & 0,95 \\
30 & 0,77 & 0,78 & 0,70 & 0,83 \\
35 & 0,88 & 0,88 & 0,91 & 0,81 \\
41 & 0,94 & 0,94 & 0,97 & 0,97 \\
\hline
\end{tabular}


Tabela 4 - Resultados das respostas dos 4 grupos de sujeitos às 9 afirmativas sobre o significado do cuidar como característica humana.

Concordamos com Leopardi (1999) que a complexidade desse fator resulta em boa parte, de uma diversidade de sensações motivadas pelas diferentes situações no cotidiano da vida dos enfermeiros, que se apresentam polarizando alegria e sofrimento, vida e morte, contrapondo-se a condições de trabalho ou estudo extenuantes, com jornadas duplas, equipes numericamente inadequadas, turnos com horários que agridem o relógio biológico, inexistência de períodos de descanso.

Segundo Germano (1993), os enfermeiros convivem com problemas ético-morais, atitudes e comportamentos incompatíveis muitas vezes com a dignidade humana, impostos pelas instituições e/ou pelas equipes de saúde, tornando-se a um só tempo refém e cúmplice do sistema.

Esses fatores aliados às questões de baixa estima profissional dos enfermeiros, pois segundo Bettinelli (2000), a profissão é vista como periférica a outras ciências, secundária socialmente, trazem sofrimento e desmotivação pessoal, elevando o nível de estresse e tornando-os mais vulneráveis a doenças e problemas comportamentais.

Cooper (1997), em um estudo com enfermeiros americanos, identificou que $80 \%$ sofriam de problemas cardiovasculares, dislipidimias, doenças grastrointestinais e problemas alérgicos e respiratórios. Conclui que o estresse seja positivo ou negativo, pode desencadear processos patológicos como os acima descritos. 
Concordamos com Doux (1992), quando afirma que o comportamento em geral e o desempenho ocupacional em particular se estende como um efeito ou condição conseqüente.

O trabalho da enfermagem não aparece institucionalmente como serviço produzido carecendo de formas de contabilização, sendo incipientes as ações de registro. Dessa forma, a profissão concorre com uma desvalorização de seu papel nos atos decisórios e organizacionais, com um status mais baixo em relação a outras categorias profissionais, pois na estrutura econômico social vigente, o que não é computável não tem valor real expresso.

Dentro dessa análise podemos perceber que a problematização valorativa do funcionamento do próprio corpo e sinais advindos do seu âmago que, por vezes são claros, intensos, metódicos, mas por outras, subliminares, sutis, intuitivos, telepáticos e premonitórios perpassam questões de extrema complexidade.

Alie-se a isso, a crescente tecnologia que hoje instrumentaliza as ações envolvendo saúde-doença exigindo dos profissionais uma constante adequação e readequação de habilidades cognitivas, comportamentais e motoras.

Silva (2000) argumenta que para cuidar do outro é antes necessário cuidar de si, pois o cuidado só acontece com a transmissão dos sentimentos e potencialidades pessoais à outra pessoa, com o intuito de ajudá-la. 
Griffin (1983) discute que o conceito de cuidar é fundamental para nossa compreensão da natureza humana, sendo que o cuidado na enfermagem adquire os aspectos de atividades e atitudes, sendo este último complexo, envolvendo fatores cognitivos, morais e emocionais.

Acreditamos que cuidar é parte do conceito que se tem de pessoa. É como nos situamos no mundo, como nos relacionamos com as outras pessoas e com o ambiente, é sobretudo o modo como nos relacionamos conosco mesmo.

Para Waldow (1999), através do modo de cuidar é que damos significado ao cuidado, imprimindo-lhe nossos valores morais e nossa cultura.

\section{2 - O cuidado como imperativo moral}

Na característica do cuidado como imperativo moral vamos encontrar as mais significativas diferenças nos resultados entre os grupos de sujeitos, no tocante às afirmativas de ordem ético moral que envolvem os sentimentos de solidariedade, de compaixão e de idealização. 
Gráfico 2 - Distribuição das respostas dos sujeitos às 9 afirmativas relativas ao conceito do significado do cuidar como imperativo moral.

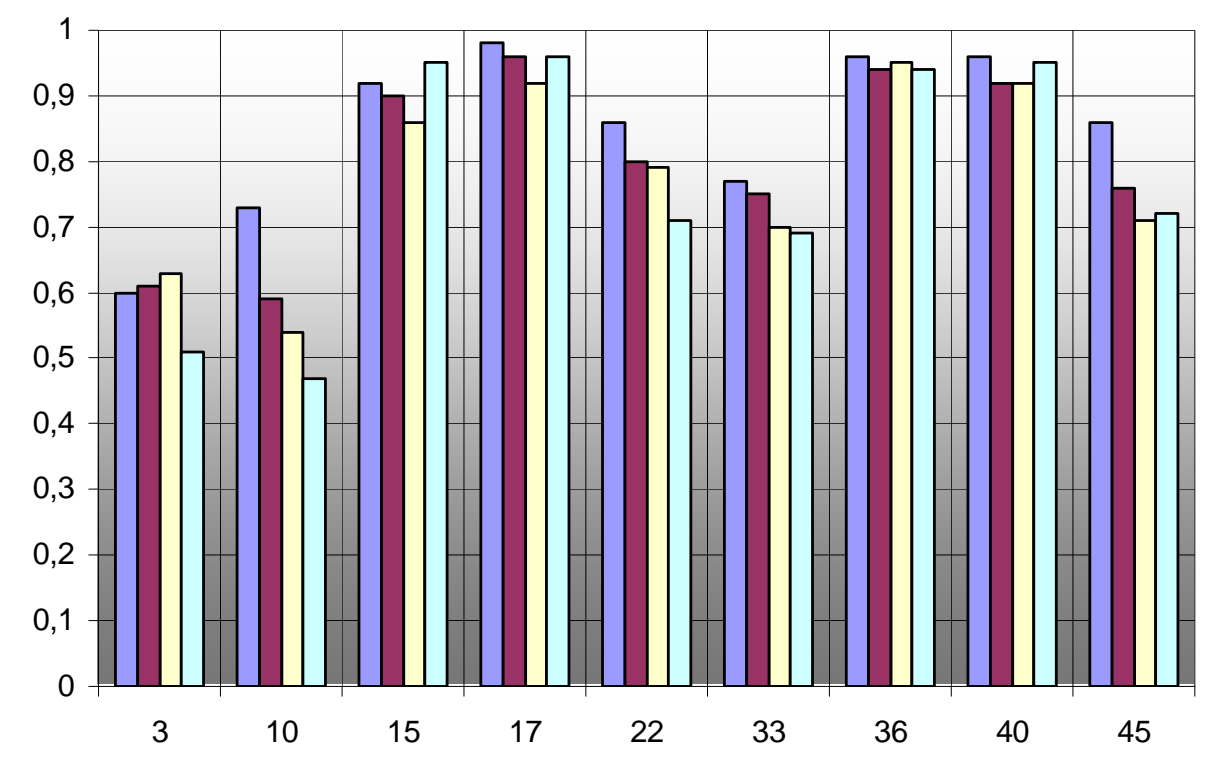

\begin{tabular}{ccccc}
\hline AFIRMATIVAS & $\begin{array}{c}\text { ALUNOS DA } \\
\text { GRADUAÇÃO }\end{array}$ & $\begin{array}{c}\text { ALUNOS DA } \\
\text { ESPECIALIZAÇÃO }\end{array}$ & ENFERMEIROS & $\begin{array}{c}\text { PROFESSORES } \\
\text { ENFERMEIROS }\end{array}$ \\
\hline 3 & 0,60 & 0,61 & 0,63 & 0,51 \\
10 & 0,73 & 0,59 & 0,54 & 0,47 \\
15 & 0,92 & 0,90 & 0,86 & 0,95 \\
17 & 0,98 & 0,96 & 0,92 & 0,96 \\
22 & 0,86 & 0,80 & 0,79 & 0,71 \\
33 & 0,77 & 0,75 & 0,70 & 0,69 \\
36 & 0,96 & 0,94 & 0,95 & 0,94 \\
40 & 0,96 & 0,92 & 0,92 & 0,95 \\
45 & 0,86 & 0,76 & 0,71 & 0,72 \\
\hline
\end{tabular}

Tabela 5 - Resultados das respostas dos 4 grupos de sujeitos às 9 afirmativas sobre o significado do cuidar como imperativo moral. 
Na afirmativa de que cuidar é um ato de compaixão, pudemos observar que somando as caselas de concordâncias e de discordâncias, a compaixão no cuidado é significante para $76,3 \%$, enquanto que somente 18,2\% dos professores tem essa opinião, com um índice de discordância de $68,1 \%$,seguidos de $39,3 \%$ e $37,9 \%$ de concordância, respectivamente dos alunos de especialização e enfermeiros da assistência.

A afirmativa de que "cuidar envolve o ideal de servir", teve o índice de concordância de $95 \%$ dos alunos da graduação, $80 \%$ dos alunos especializandos, de $72,4 \%$ dos enfermeiros da assistência e $64 \%$ dos professores. Observa-se o índice de crença decrescente, relativamente ao envolvimento com prática/ docência e anos de serviço.

Na questão "o cuidado não tem preço", chama a atenção que 41\% dos professores tinham dúvidas sobre essa alternativa.

Da mesma forma, os resultados sobre "cuidar é sinal de solidariedade" mostraram que enquanto para $90 \%$ dos alunos a afirmativa é positivamente significante, apenas $54,7 \%$ dos professores concordaram, contrapondo-se com $71,7 \%$ de adesão dos alunos especializandos e ficando próximo dos enfermeiros da assistência com 62,1\%.

Interessante foi o resultado sobre exercer a profissão, pois enquanto em média $50 \%$ dos sujeitos de todos os grupos acham a enfermagem uma profissão difícil, a totalidade respondeu que gosta de ser enfermeiro.

O cuidado humano tem sido nas últimas décadas um dos marcos referenciais da enfermagem, dando a ela uma nova perspectiva ontológica e 
que tem sido um dos temas de interesse dos estudiosos da área com enfoque na ética moral.

A ética é a ciência dos costumes e seu objeto é a moralidade, entendendo-se por moralidade a caracterização destes mesmos atos como bem ou mal.

O termo ética é usado como ciência dos costumes abrangendo diferentes campos da atividade humana. O dever em geral é o primeiro objeto da ética.

A ética natural é o ponto de partida da atuação humana podendo ramificar-se em três vertentes exclusivas: a abertura ao ser, a abertura ao eu e a abertura ao eu superior (ZANCANARO, 2000).

A ética é parte da filosofia prática, é a filosofia do que é moral e busca a análise, o aprofundamento dos atos morais de que podem ser deduzidas as normas para o ato humano.

A consciência moral é fruto do processo reflexivo e do ensino da ética como exercício pedagógico da responsabilidade tanto em questões de fronteira como do cotidiano (ZANCANARO, 2000).

Para Boff (1999) colocar cuidado em tudo é estimular a dimensão transcendente que habita em nós, possibilitando-nos sentir o outro, humano ou não, compartilhar a dor, estar junto.

Waldow (2001) refere que o cuidado humano é uma atitude ética através da qual as pessoas interagem, promovendo o crescimento e o bem estar umas das outras. 
Mayeroff (1990) usa o conceito de cuidar sob a ótica existencial, de idealização filosófica, em que o respeito ao outro no processo do cuidado, como ser individualizado faz com que se desenvolva o real significado das suas vidas, potencializando as capacidades, estimulando o desenvolvimento e o crescimento. Afirma que para que haja o cuidado é necessário que o cuidador desenvolva algumas características imprescindíveis tais como: conhecer o outro entendendo suas necessidades, adaptar seu comportamento, modificando-o ou flexibilizando-o perante as necessidades apresentadas, paciência, aceitando que o outro evolua em seu ritmo próprio, confiança que significa crer no outro e em suas potencialidades, libertando-o de dependências e incentivando-o a ousar, humildade que compreende a disposição ao novo, assim como a esperança e a coragem.

Todo esse conhecimento desenvolvido pelas inúmeras teorias tem seu palco de divulgação nas Universidades onde se constroem as práticas profissionais, pois são elas as detentoras da representação que as profissões têm para com a sociedade. As vocações e as profissões são historicamente construídas através das interações entre os homens com o meio ambiente e o grupo social.

Acreditamos que os conhecimentos incutidos durante o curso de graduação modificam as crenças e os valores que os alunos trazem introjetados culturalmente a respeito da profissão e isso delineia a construção do papel e da ação profissional. 
Concordamos com Pacheco (2001) que a universidade é o território onde podem e devem ser desenvolvidas as ferramentas que irão instrumentalizar os alunos para os diversos saberes e práticas necessários para sua formação, estimulando seu pensamento reflexivo.

Isso posto, enfatizamos o papel decisivo do professor, como condutor desse processo tornando preocupante o resultado dicotômico encontrado nos resultados dessa pesquisa. Quais os significados de cuidado como imperativo moral que são ensinados e como são praticados?

Temos a certeza de que o real aprendizado acontece com a associação de teoria e prática.

No mundo globalizado desse novo tempo ainda o poder tecnológico que, segundo Zancanaro (2000), possui efeitos perversos provocando mudanças radicais no agir contribuem para a manutenção e o desenvolvimento de modelos pedagógicos que priorizam as disciplinas acadêmicas que contemplam esse gênero de informações.

Siqueira (2002) discute que o predomínio do conhecimento departamentalizado preconizado pelo modelo clássico de disciplinas dá acolhimento ao objeto, ao corpo, à quantidade, à causalidade, à razão, ao determinismo e à essência relegando ao ostracismo o sujeito, o espírito, a qualidade, a finalidade, o sentimento, a liberdade e a existência.

A UNESCO, através da Comissão Internacional sobre a Educação para o Século XXI, desenvolveu estudos que apontam para um novo tipo de 
processo pedagógico universitário com quatro postulados: aprender a conhecer, aprender a fazer, aprender a viver junto, aprender a ser.

O papel do professor é enfatizado por Morin (2000) dentro dessa nova propositura da educação, como o mestre condutor que pode levar o educando a experimentar a criatividade, contribuindo para as transformações paradigmáticas do processo educacional contemporâneo.

A enfermagem é uma das poucas profissões que tem em seu mister o acolhimento do sofrimento humano, podendo através da instrumentalização do cuidar, ou seja, praticando o cuidado, mitigar essa dor.

A não valorização dos aspectos ético-morais que inquestionavelmente permeiam o cuidado humano pode desqualificar o cuidar como forma de ação terapêutica, tornando o ato de enfermagem um mero produto de troca e não a magnificência da terapêutica de estar com o outro, compartilhando a existência daquele momento único: o da ajuda.

Bettinelli (2002) aponta que o desenvolvimento da consciência solidária nas ações do cuidado provoca a convergência mesmo na diversidade pois funciona como catalisador, aproximando as pessoas, oportunizando uma experiência única, uma relação de encontro, de interação e reciprocidade. Ainda assim pondera o autor, como em qualquer ramo de atividade humana, também na área de enfermagem o individualismo e o egoísmo existem, com os interesses individuais sendo colocados acima dos princípios éticos e dos imperativos morais, 
ocasionando dificuldades na relação com o paciente e causando transtornos e desagregação na convivência com os parceiros de trabalho.

\section{3 - O cuidado como afeto}

Os resultados dessa categoria foram os mais uniformes, apesar de apresentarem as médias mais baixas entre todas as categorias.

Gráfico 3 - Distribuição das respostas dos sujeitos às 9 afirmativas relativas ao conceito do significado do cuidar como afeto.

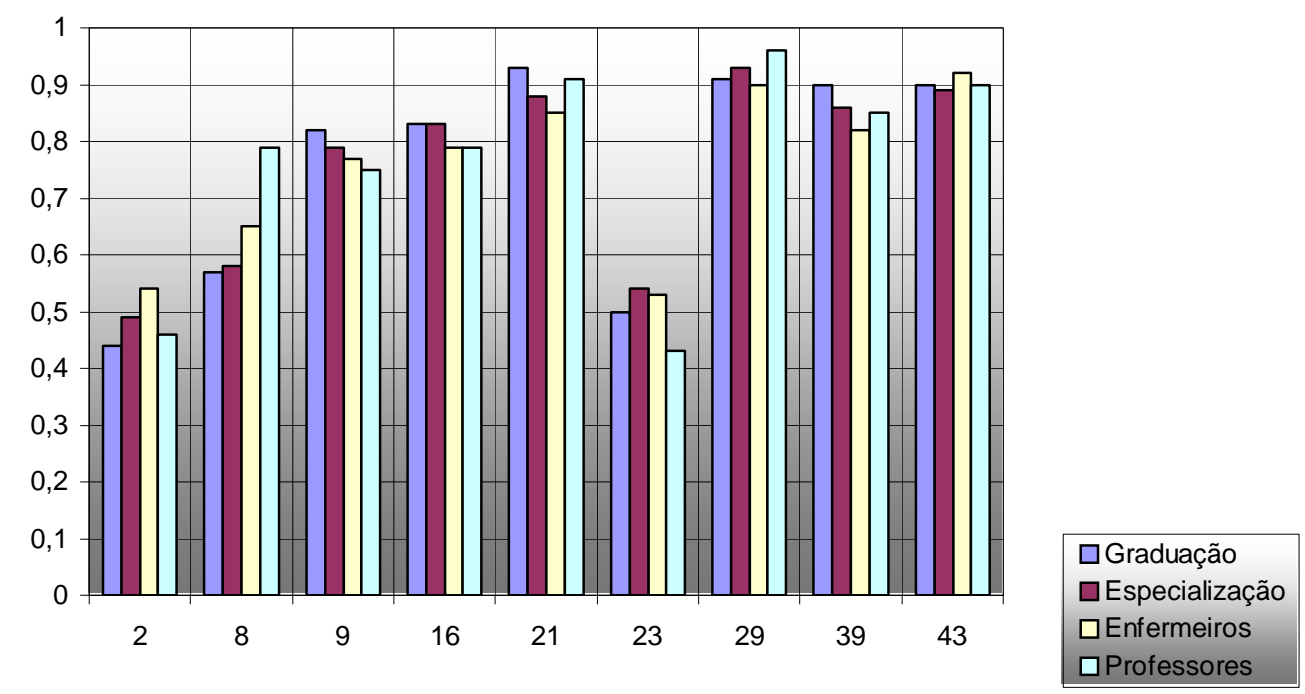

\begin{tabular}{c|ccc|c}
\hline AFIRMATIVAS & $\begin{array}{c}\text { ALUNOS DA } \\
\text { GRADUAÇÃO }\end{array}$ & $\begin{array}{c}\text { ALUNOS DA } \\
\text { ESPECIALIZAÇÃO }\end{array}$ & ENFERMEIROS & $\begin{array}{c}\text { PROFESSORES } \\
\text { ENFERMEIROS }\end{array}$ \\
\hline $\mathbf{2}$ & 0,44 & 0,50 & 0,54 & 0,46 \\
$\mathbf{8}$ & 0,57 & 0,60 & 0,65 & 0,79 \\
$\mathbf{9}$ & 0,82 & 0,80 & 0,77 & 0,75 \\
$\mathbf{1 6}$ & 0,83 & 0,80 & 0,79 & 0,79 \\
$\mathbf{2 1}$ & 0,93 & 0,90 & 0,85 & 0,91 \\
$\mathbf{2 3}$ & 0,50 & 0,50 & 0,53 & 0,43 \\
$\mathbf{2 9}$ & 0,91 & 0,90 & 0,90 & 0,96 \\
$\mathbf{3 9}$ & 0,90 & 0,90 & 0,82 & 0,85 \\
$\mathbf{4 3}$ & 0,90 & 0,90 & 0,92 & 0,90 \\
\hline
\end{tabular}

Tabela 6 - Resultados das respostas dos 4 grupos de sujeitos às 9 afirmativas sobre o significado do cuidar como afeto. 
Os índices de adesão são quase todos de consenso, a partir dos quais podemos concluir que o afeto e seus adjetivos são componentes da representação do significado do cuidado para os grupos estudados, não pairando dúvidas sobre sua incorporação nas atitudes do cuidar.

Observe-se que os escores baixos são os que tinham a afirmativa invertida negando a importância dos sentimentos do enfermeiro na afirmativa 24 e dando força à impessoalidade na afirmativa 23.

Para Boff (1999) o afeto traduz-se pela ternura com que tratamos as pessoas e os cuidados que aplicamos às situações existenciais.

Para ele, a ternura irrompe quando o sujeito se descentra de si mesmo, sai na direção do outro, sente o outro como semelhante, participa de sua existência e deixa-se tocar pela sua história.

A relação afetiva é livre, pois não subjuga nem domina, desenvolve o desejo de compartilhar caminhos.

O afeto comporta também a carícia que Boff (1999) distingue como carícia essencial por ser um modo de ser que dá plenitude nas relações que estabelece ao se transformar numa atitude. É um investimento de carinho e de amor.

Essencialmente, não existe cuidado sem carícia, ternura e amorosidade. A pessoa cordial tudo vê, tudo ouve, tudo sente, tudo percebe, tudo atende em relação ao outro ser. 
Através do afeto desenvolvemos a capacidade de olhar além, assim como de captar a extensão do real valor das coisas e das pessoas, dando significação aos fatos.

Acreditamos que o afeto manifesta-se ao deslocarmos o nosso foco do saber sobre o outro, para o do conhecer o outro, olhando-o em, os entres e os aléns de sua identidade, exercitando e excitando os órgãos sensoriais para que possamos sentir as reais necessidades do ser, desenvolvendo a percepção para captarmos suas dores físicas, morais ou existenciais.

A afetuosidade estimula o envolvimento e ocasiona o vínculo, despertando a sensibilidade, o que leva a um círculo virtuoso.

As manifestações de sentimentos pelo enfermeiro são entendidas pelos pacientes e às vezes até pelos próprios profissionais, como atos de bondade, característica individual e volitiva daquele sujeito.

Importante se faz distinguir que a afetuosidade é habilidade sensorial a ser estimulada e desenvolvida no preparo para o exercício profissional, por ser fundamental na ministração do bom cuidado.

Faz-se necessário entender que os afetos constituem esquemas funcionais, comportamentais, relacionais, adaptativos, conectados intimamente com qualquer outro esquema funcional ou estrutural da mente. Eles condicionam os pensamentos, estando ligados à percepção na sua expressividade interpessoal direta (gesto, mímica, motricidade, odores).

Afeto e sua comunicação resultam ligados inclusive às formas perceptivas elementares (DOUX, 1998). 
Afeto como conduta é sempre uma reação entre objeto interno e externo sendo um indicador perceptivo do que ocorre num dado momento, em uma situação definida (BLEGER, 1989).

A educação é um elemento integrante da cultura havendo estreita relação entre educação e personalidade, entre conduta e cultura, portanto, é possível transmitir a afetividade do cuidado pelo ensino.

Podemos descrever os afetos, com base naquilo que sente e nos conta um paciente, ou com base na sua expressão facial, corporal, postural ou com base naquilo que podemos constatar do seu modo de se comportar nas relações com as pessoas.

As teorias vão sendo substituídas à medida que a ciência progride e os novos desvendamentos dos estudos da mente apontam proposituras de cunho holístico e ecológico no desenvolvimento das emoções e sentimentos.

$\mathrm{O}$ afeto como forma de sentir adquirida condiciona o modo pela qual a experiência é vivenciada, ou seja, elaborada, assimilada, codificada na memória.

É impossível haver afeto sem sentido e sentido sem afeto.

Heidegger (1989) postula que cuidado é sinônimo de relações de amor ou de amizade envolvendo o cuidar da pessoa ou objeto amado.

Koromita (1993) discute que o cuidado envolve dar assistência ao sentimento do indivíduo na mesma amplitude com que se atende suas necessidades básicas. Significa ser profissionalmente afetuoso no cuidado, 
sem confundir isto com sentimento pessoal de amor, amizade, paixão ou identificação.

Acreditamos que um dos sustentáculos do reconhecimento profissional é sem dúvida a retomada às fundamentações originais da profissão, quando o cuidado estava intimamente ligado a atitude de amar e a ação de cuidar. Através dessa manifestação fluía o cuidado. Incorporar os avanços da tecnologia, ampliar as bases científicas, desenvolver os métodos de aplicação do conhecimento às mais sensitivas formas de cuidar é calcar no imaginário social as marcas indeléveis da enfermagem como a artífice do cuidado terapêutico.

\section{4 - O cuidado como relação interpessoal}

Nas afirmativas sobre cuidar como relação interpessoal, não encontramos diferenças entre grupos, havendo consenso quanto às concordâncias das questões, com índices bastante próximos de adesão.

Dentro dos enfoques do cuidado, as relações interpessoais desde a metade do último século têm merecido uma acurada atenção, o que pode ser comprovado através do desenvolvimento de teorias de enfermagem que esmiúçam o tema.

Nos estudos de Rodrigues (1996) e Furegato (1999) o tema das relações interpessoais toma postulado terapêutico, cientificando a ação de enfermagem como uma relação de ajuda profissional humanizada. A autora 
introduz um novo conhecimento sobre o assunto, quando possibilita um movimento transdisciplinar ao conjugar as relações interpessoais na enfermagem, com a análise de conteúdos do processo interativo na comunicação enfermeira / paciente.

Assim sendo podemos pensar o cuidado de enfermagem como um processo de interações com relações profissionais particularizadas, mas, que conjugam um mesmo ambiente, interagindo com ele e por ele sendo influenciado.

O processo interativo é um elemento integrador entre os seres, o meio social e o cosmo, contribuindo para um ambiente de cuidado terapêutico.

Acreditamos que a educação profissional deva continuar privilegiando esse aprendizado que com certeza oportuniza a simbiose entre o enfermeiro e o paciente favorecendo o bem cuidar e construindo outros modelos de assistência fundamentados nos princípios humanizados das ciências atuais.

O professor deve ser o condutor do processo interativo, ajudando alunos e pacientes a decifrarem os sinais emitidos, decodificando-os através da comunicação e promovendo os movimentos e mecanismos para que se estabeleça a relação de ajuda. 
Gráfico 4- Distribuição das respostas dos sujeitos às 9 afirmativas relativas ao conceito do significado do cuidar como relação interpessoal.

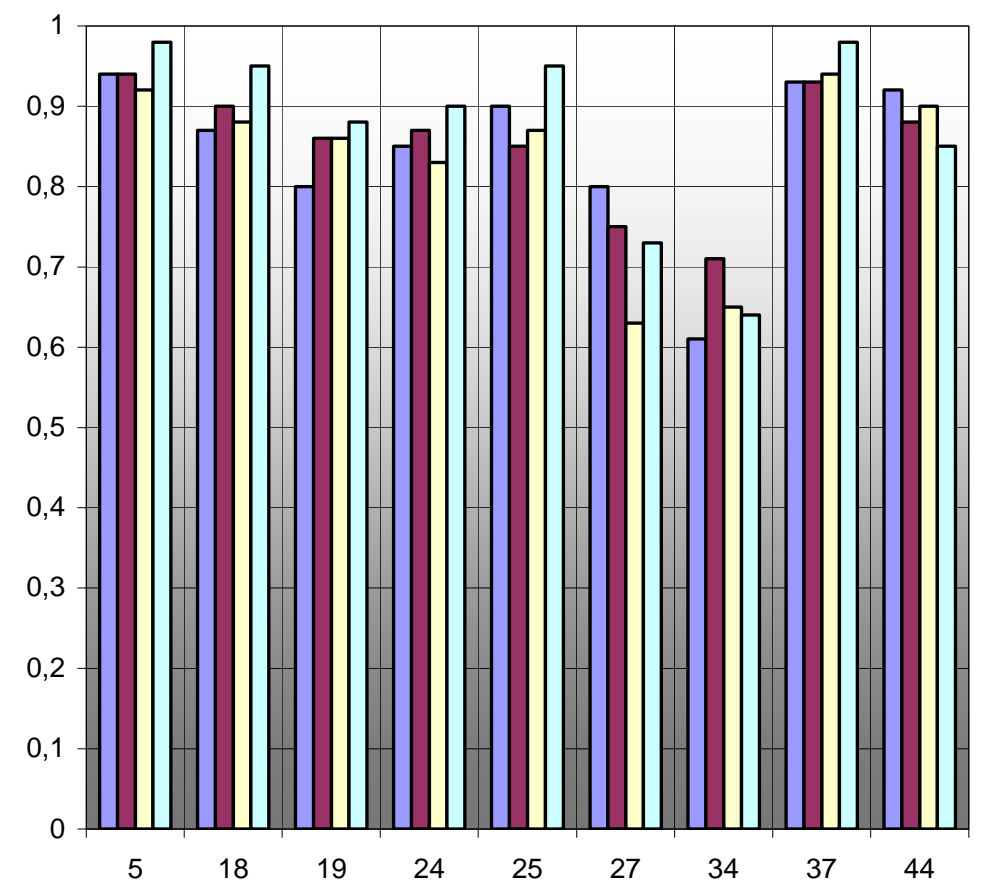

\begin{tabular}{ccccc}
\hline AFIRMATIVAS & $\begin{array}{c}\text { ALUNOS DA } \\
\text { GRADUAÇÃO }\end{array}$ & $\begin{array}{c}\text { ALUNOS DA } \\
\text { ESPECIALIZAÇÃO }\end{array}$ & ENFERMEIROS & $\begin{array}{c}\text { PROFESSORES } \\
\text { ENFERMEIROS }\end{array}$ \\
\hline 5 & 0,94 & 0,94 & 0,92 & 0,98 \\
18 & 0,87 & 0,90 & 0,88 & 0,95 \\
19 & 0,80 & 0,86 & 0,86 & 0,88 \\
24 & 0,85 & 0,87 & 0,83 & 0,90 \\
25 & 0,90 & 0,85 & 0,87 & 0,95 \\
27 & 0,80 & 0,75 & 0,63 & 0,73 \\
34 & 0,61 & 0,71 & 0,65 & 0,64 \\
37 & 0,93 & 0,93 & 0,94 & 0,98 \\
44 & 0,92 & 0,88 & 0,90 & 0,85 \\
\hline
\end{tabular}

Tabela 7- Resultados das respostas dos 4 grupos de sujeitos às 9 afirmativas sobre o significado do cuidar como relação interpessoal. 


\section{5 - O cuidado como intervenção terapêutica}

Pudemos observar nos resultados encontrados nessa característica uma concordância acentuada e bastante semelhante entre os grupos, o que vem corroborar uma tendência da cultura profissional contemporânea em valorizar acentuadamente os elementos objetivos, concretos, tecnicistas, numa reprodução hegemônica do modelo científico cartesiano que ainda estrutura as profissões de saúde, mas que ao mesmo tempo tenta incorporar em seu cabedal de conhecimentos, o novo, o improvável, o subjetivo, o lúdico, o emocional, o espiritual.

A intervenção terapêutica é uma ação que visa o restabelecimento do equilíbrio, a normalização ou ainda o alívio ou mesmo o amparo de uma situação desestabilizada, de desconforto, de infortúnio ou de dor. Para tanto deve estar ancorada em referenciais que estabeleçam os padrões que caracterizem as fronteiras entre saúde e doença.

A enfermagem tem incorporado em seus sistemas de assistência as profundas mudanças por que tem passado a sociedade, que em curto espaço de tempo passou da era da comunicação para a da informação, chegando aos dias atuais adentrando na era virtual, com as realidades regionais mais e mais globalizadas e vivenciadas em tempo real pelo ciberespaço, acarretando mudanças frondosas de paradigmas, que alcançam também e vigorosamente o conteúdo e a prática da profissão. 
Levantam-se questões ontológicas tanto quanto epistemológicas de ser e fazer, o que tem contribuído para uma reflexão mais intensa da atuação profissional, dos papéis que desempenham os enfermeiros e de como o cuidado é entendido, transmitido e operacionalizado, como uma das marcas de referência da profissão.

Entendemos que nesses novos tempos, os processos pedagógicos deverão formar enfermeiros capazes de desempenhar suas atividades de modo responsável, autônomo, seguro, habilidoso nas questões técnicas e com desenvoltura para os avanços tecnológicos, mas que inclua nesse desempenho a convivialidade que denota, segundo Boff (1999) e Buscaglia (1997), a capacidade de fazer conviver as dimensões de produção e de cuidado, de efetividade e de paixão, a aptidão para manter o equilíbrio multidimensional entre homens, sociedade e a natureza, reforçando o sentido de compatia.

Combinar o valor técnico da produção material com o valor ético da produção social e espiritual da enfermagem é, com certeza, a grande arte da profissão, mas inquestionavelmente é também o seu maior desafio. 
Gráfico 5- Distribuição das respostas dos sujeitos às 9 afirmativas relativas ao conceito do significado do cuidar como intervenção terapêutica.

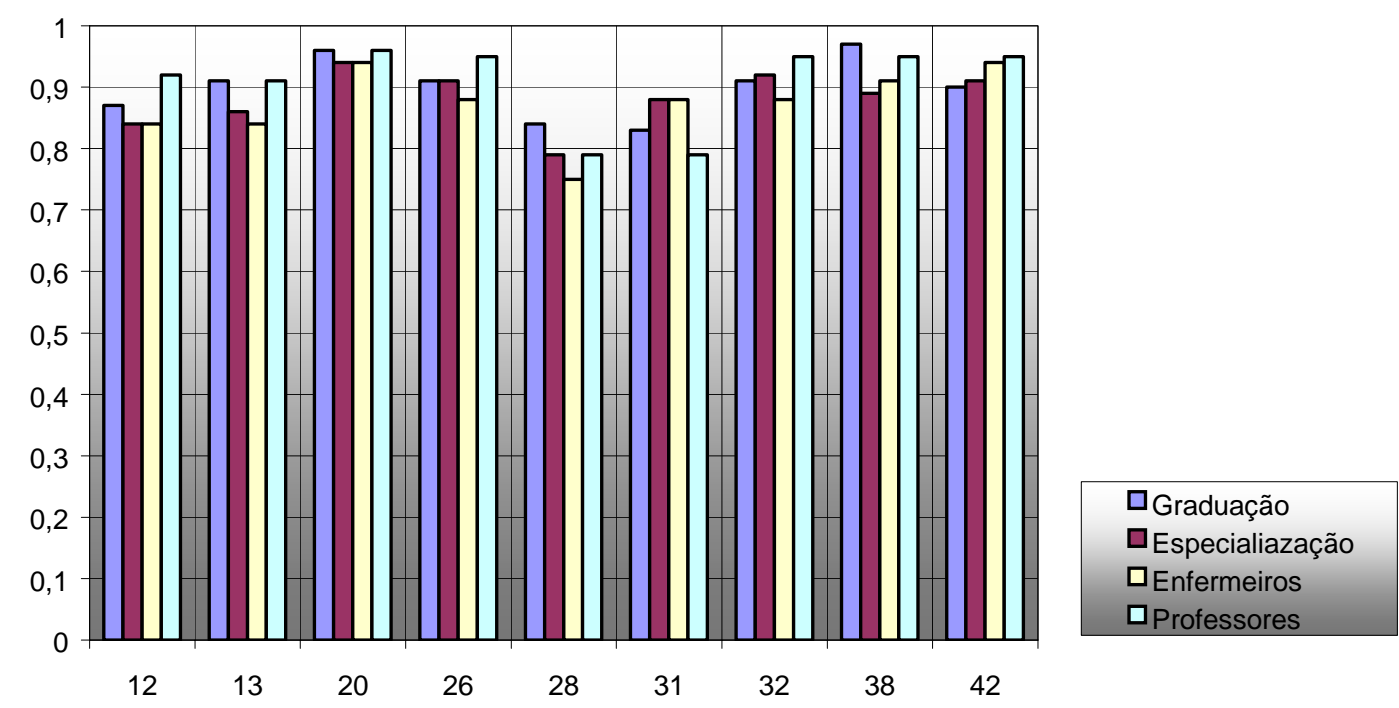

\begin{tabular}{ccccc}
\hline AFIRMATIVAS & $\begin{array}{c}\text { ALUNOS DA } \\
\text { GRADUAÇÃO }\end{array}$ & $\begin{array}{c}\text { ALUNOS DA } \\
\text { ESPECIALIZAÇÃO }\end{array}$ & $\begin{array}{c}\text { ENFERMEIROS } \\
\text { PROFESSORES } \\
\text { ENFERMEIROS }\end{array}$ \\
\hline 12 & 0,87 & 0,80 & 0,84 & 0,92 \\
13 & 0,91 & 0,90 & 0,84 & 0,91 \\
20 & 0,96 & 0,90 & 0,94 & 0,96 \\
26 & 0,91 & 0,90 & 0,88 & 0,95 \\
28 & 0,84 & 0,80 & 0,75 & 0,79 \\
31 & 0,83 & 0,90 & 0,88 & 0,79 \\
32 & 0,91 & 0,90 & 0,88 & 0,95 \\
38 & 0,97 & 0,90 & 0,91 & 0,95 \\
42 & 0,90 & 0,90 & 0,94 & 0,95 \\
\hline
\end{tabular}

Tabela 8- Resultados das respostas dos 4 grupos de sujeitos às 9 afirmativas sobre o significado do cuidar como intervenção terapêutica. 


\section{B - Comparação dos resultados dos grupos em sua totalidade com relação às categorias.}

Encontramos na comparação dos totais dos grupos, resultados que mostram diferenças significativas nos percentuais de concordância e discordância, sendo que as questões sobre os significados do cuidar como característica pessoal humana e como imperativo moral são as que mostram as diferenças mais acentuadas, principalmente entre os agrupamentos alunos da graduação e professores em relação ao agrupamento de alunos da especialização e enfermeiros da assistência.

Os percentuais das questões sobre o afeto são os que apresentam a maior semelhança, apesar de ter sido o menor percentual obtido, o que demonstra a maior quantidade de discordâncias nas afirmativas.

Nos resultados das questões sobre o cuidado como relação interpessoal encontramos semelhanças entre as médias dos grupos, com valores altos de concordância, o que reafirma os achados nos referenciais bibliográficos, que mostram ênfase a estes aspectos na formação e atuação do enfermeiro.

Os maiores escores encontrados nos resultados dos quatro grupos foram os relativos ao cuidado como intervenção terapêutica, demonstrando que a aplicação do conteúdo cientifico está atingido um dos seus objetivos, que é a profissionalização do cuidado, tornando-o um dos marcos referenciais da enfermagem. 
Gráfico 6 - Distribuição dos resultados dos grupos em sua totalidade em relação às características estudadas.

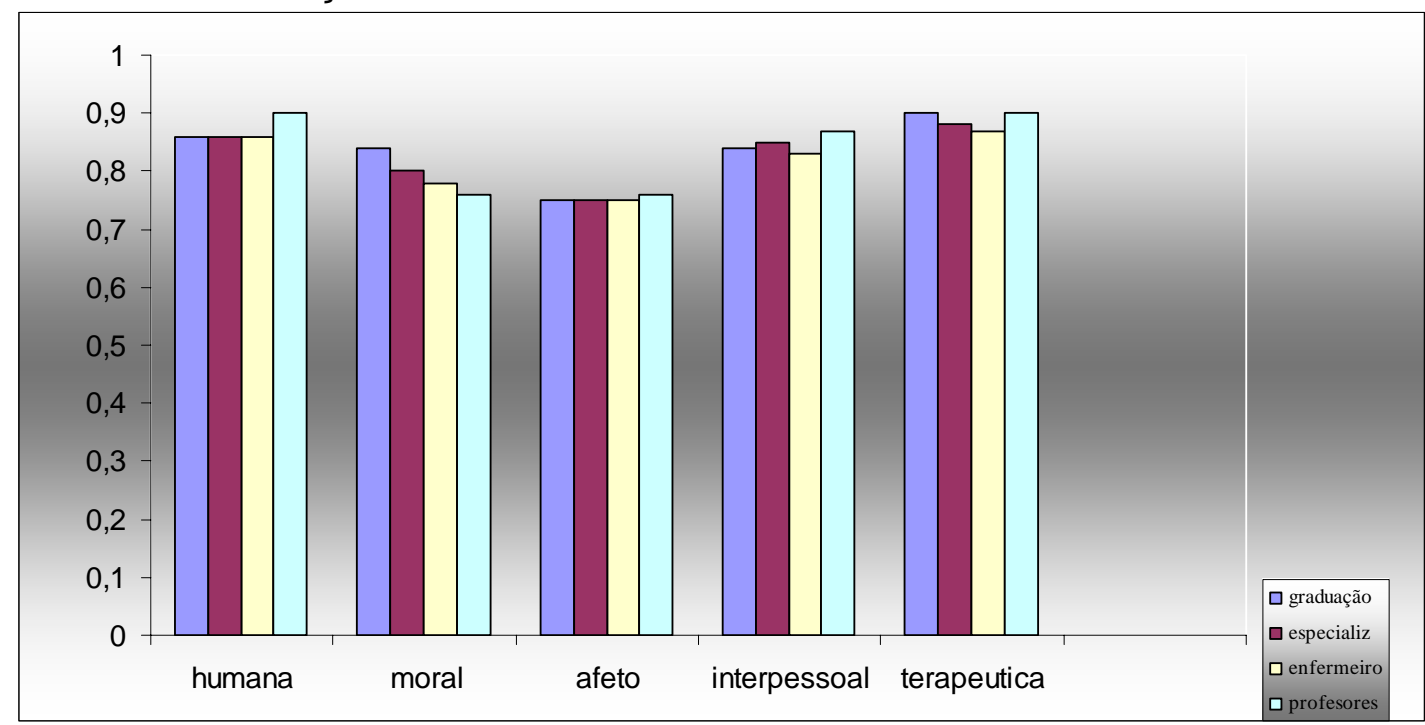

\begin{tabular}{c|cccc}
\hline $\begin{array}{c}\text { Amostra } \\
\text { Categoria }\end{array}$ & Graduação & Especialização & Enfermeiros & Professores \\
\hline $\begin{array}{c}\text { Pessoal } \\
\text { Humana }\end{array}$ & 0,86 & 0,86 & 0,86 & 0,90 \\
\hline $\begin{array}{c}\text { Imperativo } \\
\text { Moral }\end{array}$ & 0,84 & 0,80 & 0,78 & 0,76 \\
\hline Afeto & 0,75 & 0,75 & 0,75 & 0,76 \\
\hline $\begin{array}{c}\text { Relação } \\
\text { Interpessoal }\end{array}$ & 0,84 & 0,85 & 0,83 & 0,87 \\
\hline $\begin{array}{c}\text { Intervenção } \\
\text { Terapêtica }\end{array}$ & 0,90 & 0,88 & 0,87 & 0,90 \\
\hline
\end{tabular}

Tabela 9 - Resultados das respostas dos grupos em relação às características estudadas. 
Nos estudos de Morse (1998) fica patente que uma categoria tem característica fundamental em comum para determinar sua filiação nessa categoria, pois estruturas de categoria são organizadas em torno de um conjunto de propriedades e de atributos conectados, baseados em similaridade.

Quanto mais abstrato o conceito, mais complexo torna-se identificar esses atributos. Todos os conceitos são resultados de instâncias particulares que se tornaram gerais, por serem tratadas como um modo de tipo ou regra. Esses significados gerais são estabilizados com o uso da linguagem em processos de interação social, onde os resultados de coordenação e os elementos inerentes são ordenados pela mesma relação. As pessoas percebem um conceito como um meio de organizar acontecimentos e elaboram que o conceito seja capaz de ser aplicado instantaneamente aos acontecimentos.

Dessa forma, ocorre uma relação recíproca entre os atos interpretativos pelos quais construímos nossos modelos de realidade e as propriedades da realidade em si.

Morse (1998) postula que a identificação dessas regras de relações que caracterizam as várias manifestações de percepções de cuidado são obtidas com maior fidedignidade através de métodos de inquirição qualitativa, utilizando-se de dados observacionais e de entrevistas, técnicas 
de análise secundária empregando-se a literatura como uma fonte de dados, sendo sempre a revisão bibliográfica crucial para o processo.

Nos estudos desenvolvidos e pesquisados por nós através do referencial bibliográfico pudemos constatar que o conceito e as percepções do cuidado aparecem bem desenvolvidos, mas a aplicação parece problemática, pois a análise, assim como os achados em nossa pesquisa revelaram que os conceitos de cuidado não correspondem às situações de enfermagem para as quais se esperava que fossem usadas. Além disso, as afirmações construídas, não eram consideradas com a freqüência que as teorias preconizavam.

Acreditamos ainda que a prática da enfermagem apóia-se mais em vieses das outras ciências tradicionais, denotando os enfermeiros uma ausência de conhecimentos de teorias próprias, ou ainda uma falta de coesão e por que não, de valorização dos conhecimentos e significados da própria profissão.

Inúmeras são as inquirições da prática de enfermagem que não encontramos descritas, discutidas e avaliadas, persistindo uma dicotomia entre a produção do conhecimento e o consumo de pesquisa, entre o saber e o fazer.

Concordamos com Bettinelli (2002) Leopardi (2001) e Waldow (2000), que é emergencial a promoção de estudos e trabalhos que tragam à reflexão essas questões pouco expressas pelas pesquisas mas que são vivenciadas em profundidade no cotidiano. 
A coesão entre uma valorização do pensar, do fazer, do ser tecnicista, asséptico, desprovido de vínculos e a do perceber, do sentir, do tocar, contaminado de emoções é, com certeza, a empreitada de maior envergadura que a educação em enfermagem, enquanto formação profissional deverá se empenhar em busca da equidade. 


\section{V - CONSIDERAÇÕES FINAIS}

No presente trabalho, propusemo-nos a analisar as percepções do cuidado/cuidar e suas relações entre as pessoas envolvidas com a assistência e o ensino de enfermagem (alunos de graduação, alunos de especialização, enfermeiros da assistência e professores/enfermeiros) que atuam em instituições da área da saúde, uma vez que o cuidado e o cuidar constituem a essência da profissão.

O cuidado como uma conduta implica uma gama de atitudes e sentimentos que permitem a quem o executa e a quem o recebe uma interação capaz de produzir efeitos extremamente benéficos para ambas as partes.

Falamos em afeto, em conforto, em compaixão, em zelo, em colocarse totalmente no lugar do outro, em ser terapêutico.

É necessário dar ênfase a esses aspectos no ensino acadêmico, pois são os professores os responsáveis pela formação dos futuros profissionais. São eles os verdadeiros condutores de idéias e valores a serem 
sedimentados, garantindo que os enfermeiros efetivamente possam atuar seguindo os preceitos éticos dentro de uma atividade voltada ao bem-estar de pessoas que vivem um episódio de sofrimento e de dor.

Daí nossa preocupação em conhecer como os envolvidos no ensino e na prática da enfermagem concebem os conceitos de cuidado e de cuidar.

Para sistematizar a busca de respostas procedemos a elaboração de um instrumento para conhecer os significados do cuidado amparados no referencial teórico de JANICE MORSE. Após profundos estudos bibliográficos sobre os conceitos do cuidado e do cuidar foram identificadas as concepções que apresentaram maior freqüência nos resultados, classificando-os em cinco categorias: o cuidado como característica pessoal humana, o cuidado como imperativo moral, o cuidado como afeto, o cuidado como relação interpessoal, o cuidado como intervenção terapêutica. Destes procedimentos resultou a Escala de Avaliação do Significado do Cuidar (EASC), testada e aplicada conforme indicado na literatura.

Os resultados apontaram para achados semelhantes aos da literatura internacional, nacional e do arcabouço teórico de MORSE (1990), no qual nos amparamos para fundamentar a hipótese desse estudo.

A análise conduz para a necessidade de implantar no ensino acadêmico processos pedagógicos que se preocupem com a afinação entre o preconizado na teoria e a forma como é transmitido o conhecimento, inclusive na prática, pois se salientam nos achados, as diferenças entre as concepções dos professores em relação aos demais grupos de sujeitos, com 
destaque nas questões relativas ao cuidado como característica pessoal humana em que na amostra dos professores a média obtida foi maior $(0,90)$ em comparação aos outros grupos que apresentaram médias iguais $(0,86)$ e nas atinentes ao cuidado como imperativo moral onde pode ser observada a média resultante das respostas dos alunos de graduação relativamente maior $(0,84)$ que as médias dos outros grupos, sendo a diferença mais acentuada em relação à média do grupo de professores $(0,76)$.

Concordamos com Buscaglia (1990), quando afirma que a ação humana é imbuída de sentimentos e emoções que dão o tom aos comportamentos, movimentando o ser humano no rumo de suas querências frente aos questionamentos existenciais que o preocupa.

Pensamos que o cuidado humano é a exteriorização de um estado de valor próprio. Quando as pessoas se identificam em seus papéis e se sentem integradas em seu meio, inevitavelmente se tornam mais motivadas, com elevada auto-estima, com percepção de si e dos outros que estão a sua volta, preocupadas em ter suas necessidades preenchidas, assim como em contribuir para com a satisfação das necessidades dos outros.

A amostra este estudo foi constituída por 171 sujeitos, sendo 21 alunos de graduação, 99 alunos de pós-graduação, 29 enfermeiros da assistência e 22 professores/enfermeiros.

Os dados do perfil dos sujeitos mostram semelhanças e diferenças interessantes entre os grupos. 
O grupo de graduandos tem uma média de 29 anos, os especializandos 32 anos e entre os enfermeiros da assistência a idade média é de 34 anos e a dos professores, de 35 anos. A representação feminina é maciça em todos os grupos.

Dentre os alunos da graduação, 47,6\% residem em Araras e 52,3\% em cidades da região. Dentre os alunos da pós-graduação esse dado passa a ser inverso, com 18,2\% de Araras e $80,8 \%$ de outras cidades e regiões.

Os enfermeiros da assistência residem na cidade de Araras $(96,5 \%)$ e dentre os professores, $54,5 \%$ residem no município e $45,5 \%$ em cidades próximas.

Dos alunos de graduação, 47,6\% moram com as famílias, 23,8\%, com amigos e 19,1\% sozinhos. Diferentemente os alunos de especialização, os enfermeiros e os professores, morando com os familiares $(56,9 \%, 89,7 \%$ e $90,9 \%)$

Está equilibrado o percentual dos alunos que trabalham durante o curso $(47,6 \%)$.

A média de anos de trabalho na enfermagem é de 8,6 para os alunos da pós-graduação, 11,5 para os enfermeiros da assistência e 14,8 para os professores enfermeiros.

Quanto à continuidade dos estudos, observa-se que, dentre os alunos da pós-graduação, 21,2\% já tinham freqüentado outra especialização e 2,1\% estavam em cursos de mestrado. 
Dentre os enfermeiros da assistência, 51,7\% tinham uma especialização concluída e $24,2 \%$ a estavam cursando, assim como 3,45\% estavam matriculados em programas de mestrado.

Em relação aos professores/enfermeiros, verifica-se a presença de 68,2\% com especialização e 54,5\% com mestrado concluído, assim como $18,2 \%$ freqüentando cursos de mestrado e 9,1\%, de doutorado.

A renda média familiar da população do estudo variou de 02 salários mínimos para o grupo de alunos da graduação, 05 para os alunos da especialização, 3,5 para os enfermeiros da assistência e, finalizando, 10 para os professores enfermeiros. Esse dado corrobora os inúmeros estudos mercadológicos que enfatizam que quanto mais tempo de estudo um profissional tem em seu currículo, maior é sua faixa de renda.

Ao verificar se eram ou não significantes as diferenças entre os 04 grupos e entre as categorias, os resultados da Escala do Significado do Cuidar (EASC) apontaram para diferenças conceptuais entre os grupos e entre as categorias em relação à amostra deste estudo.

Verificamos na distribuição da mediana das 5 categorias com os 4 grupos de sujeitos, que ocorreu, na categoria de Significados do Cuidar como Imperativo Moral, uma variação significativa de um grupo para outro, mais acentuada no grupo 1 (alunos da graduação), com um nível de significância de 0,43.

As maiores diferenças evidenciam-se entre as concepções de alunos e professores, especialmente nas concepções de cuidado como 
característica humana e como imperativo moral. Pensamos que essa diferença pode se dar pelo fato do aluno graduando aspirar pelos ideais profissionais e estar voltado para as expectativas do futuro em relação ao seu papel no mercado de trabalho.

Nas questões relativas ao afeto, temos a maior uniformidade de resultados entre os 4 grupos, assim como também as menores médias obtidas, o que demonstra ter sido a categoria com maior índice de desacordos.

Nas categorias, no seu conjunto, os escores de professores e alunos são próximos, assim como os de especializandos e enfermeiros da prática, com diferenças significativas entre os dois agrupamentos, o que reafirma o disposto na literatura, nas discussões sobre a teoria e a prática, ressaltando a necessidade de que sejam concentrados os esforços para a elaboração de mais estudos sobre o tema.

É relevante que ponderemos sobre a grande influência que professores exercem sobre os alunos, sendo visualizados por estes como modelos a serem seguidos. Por esse motivo são necessários muita atenção e vigilância, para que na transmissão dos conhecimentos, na orientação das atitudes e no desenvolvimento das habilidades, o façamos com um evidente alto grau de confiança interpessoal, com processos de comunicação autêntica e lealdade de propósitos, buscando o real envolvimento com os objetivos do ensino e com as bases epistemológicas e ontológicas da profissão. 
Não tivemos neste estudo a pretensão de elucidar o assunto, mas dentro do nosso espaço e vivência profissional analisar um recorte da vida dos atores que a protagonizam e, dentro dos limites dessa realidade, refletir sobre os questionamentos que fazem parte desse cotidiano.

Pensar e refletir sobre a enfermagem como a terapia do cuidado é a contribuição que podemos extrair deste estudo que, para nós, é somente o ponto de partida para um rumo que possibilita vislumbrar a sedimentação de processos ontológicos e epistemológicos do sentido do cuidado e do ato terapêutico. Como pondera Volich (2000), o termo terapeuta deriva da raiz etimológica grega "eu cuido", sendo o terapeuta (thérapéuo) aquele que compartilha a experiência de sofrimento do doente, compreendendo-o, auxiliando-o, colocando-se junto, interessando-se pela totalidade da sua vida e, a partir daí, mobiliza os seus conhecimentos e recursos para promover a arte do cuidar. Seu foco era o acolhimento da dor, o cuidado ao ser.

O papel do professor é preponderante nas perspectivas atuais da educação, pois como tutor pode conduzir o aluno a vivenciar novos espaços, estimulando atitudes cívicas, sintômicas, solidárias, éticas, constitutivas e respeitosas; estimular-lhes a noção de valor e as criações que fazem sentido; ensinar-Ihes a pautar a existência pela procura do significado verdadeiro da experiência de vida; e contribuir para a evolução do modelo educacional contemporâneo.

Ao longo da história do século XX, a enfermagem sedimentou-se como profissão e, num fenômeno global, tem tido cada vez mais um 
proeminente papel dentre as profissões da saúde voltadas para o cuidado, destacando-se entre elas por sua eficiência, sua eficácia, sua efetividade e sua relevância.

Acreditamos que bons resultados são alcançados quando as pessoas trabalham em conjunto, integradas, a partir de relações de cooperação e compromisso. Esses fatores são resultantes do caráter, dos princípios e dos valores das pessoas e exteriorizados através dos padrões de comportamento que, por sua vez, envolvem conhecimento, atitudes e habilidades.

Assim, faz-se mister readequarmos o nosso saber de enfermagem e nosso fazer de enfermeiros sob as luzes desse novo tempo que, segundo Toffler (1998) será a era das relações inter e transpessoais fundamentais para a educação dos enfermeiros.

Importante se faz ensinar que a complexidade é um desafio que nos incita a pensar de uma forma diferente, incluindo nesse pensar a ambivalência, o antagonismo, a concorrência entre opostos que ao mesmo tempo se completam.

Devemos direcionar nosso olhar para além do aparente e refletir sobre todo o acima exposto, para que o processo educacional seja cada vez mais libertador, propicie a formação de profissionais com mentes e almas abertas às mais variadas experiências, promova seres humanos profissionalizados e cidadãos com mais saúde, com mais consciência de si, com mais capacidade para compreender e amar o próximo, com mais 
compreensão dos mecanismos da natureza, com equilíbrio emocional e acentuada espiritualidade. 


\section{VI - REFERÊNCIAS BIBLIOGRÁFICAS}

ANASTASI, A. Evolving concepts of validation. Annu. Rev. Psychol, v.37, p.1-15, 1986.

ARRUDA, E. N. Cuidando - confortando: um programa emergente de pesquisa em enfermagem. Texto \& Contexto enfermagem, v.3 n.1, p. 11627, 1994.

AURÉLIO, B. H. F. Novo dicionário da Língua Portuguesa. Rio de Janeiro: Nova Fronteira, 1975.

BEM, J. D. Convicções, atitudes e assuntos humanos. Tradução Carolina M. Rossi. São Paulo: EPU, 1973.

BETTINELLI, L. A. A solidariedade no cuidado: dimensão e sentido da vida. Florianópolis: UFSC/PEN, 2002.

BISON, R. A. P. Representações sociais dos estudantes de enfermagem sobre sexualidade, numa experiência de ensino. Ribeirão Preto, 1998. Dissertação (Mestrado) - Escola de Enfermagem de Ribeirão Preto, Universidade de São Paulo. 
BLAY, S. L. Comentários do debatedor: escalas de avaliação utilizadas em múltiplos quadros. Rev. Psiq. Clín., v.26, n.2, p. 106-7, 1999. Edição especial.

BLEGER, J. Psicologia da conduta. Porto Alegre: Artes Médicas, 1989.

BOFF, L. Saber cuidar: ética do humano - compaixão pela terra. Petrópolis: Vozes, 1999.

BRAGHIROLLI, E. M.; PEREIRA, S.; RIZZON, L. A. Temas de psicologia social. Petrópolis: Vozes, 1994.

BUSCAGLIA, L. Amor. Rio de Janeiro: Record, 1972.

COOPER, K. H. Can stress heal? Nashville: Thomas Nelson, 1997.

DOUX, L.J. O cérebro emocional - Os misteriosos alicerces da vida emocional. Editora Objetiva. Rio de Janeiro.1998.

DUPAS, G. O Processo de cuidar em enfermagem: com a palavra os enfermeiros de uma instituição hospitalar. Acta Paul. Enfermagem, v.12, n.2, p. ,1999.

FAZIO, R. H. Motives for social comparison: the construction-validation distinction. J. Pers. Soc. Psychol., v.37, n.10, p. 1683-98, 1979.

FUREGATO, A. R. F. Relações interpessoais terapêuticas na enfermagem. Ribeirão Preto: SCALA,1999. 
GAMBOA, N. S. G. Cuidar para enfermeiros da UTI Neonatal: descrição das categorias significantes. São Paulo, 1997. Dissertação (Mestrado) Escola de Enfermagem, Universidade de São Paulo.

GAUT, D. Development of a theoretically adequate description of caring. West. J. Nurs. Res., v.5, n.4, p.313-24, 1983.

GEORGE, J. Teorias de enfermagem: os fundamentos para a prática profissional. Porto Alegre: Artes Médicas, 1993.

GERMANO, R. M. A ética e o ensino de ética na enfermagem do Brasil. São Paulo: Cortez,1993.

GRIFFIN, A. P. A philosophical analysis of carig in nursing. J. Adv. Nurs., v.8, p.289-95, 1983.

HEIDEGGER, M. A tese de Kant sobre o Ser. São Paulo: Duas Cidades, 1970.

. Conferências e escritos filosóficos. São Paulo: Nova Cultural, 1989.

. Ser e Tempo. 5. ed. Petrópolis: Vozes, 1997.

JOHNSON, J. L. A dialectial examination of nursing art. Adv. Nurs. Sci. v.17, n.1, p. 1-14, 1994.

KING, I. M. Toward a theory for nursing: systems, concepts, process. New York: Wiley, 1981. 
KOMORITA, N. I. Perceptions of caring by nurse educators. J. Nurs. Educ., v.30. n.1, p. , 1991.

LEININGER, M. Transcultural nursing: concepts, theories and pratice. New York: John Wiley \& Sons, 1978.

LEOPARDI, M. T. Teorias em Enfermagem: instrumentos para a prática. Florianópolis: NFR/UFSC; Papa-Livros, 1999.

LEVINE, M. E. Holistic nursing. Nurs. Clin. N. Am., v.6, p.253-64, 1971.

LIMA, M.L.P.de. Atitudes. In: VALLA, J.; MONTEIRO, M.B. Psicologia Social. Lisboa: Fundação Calouste Gulbenkian, 1993.

MAYEROFF, M. On Caring. New York: Harper Perennial, 1990.

McGUIRRE, J. W. The nature of attitudes change. In: LINDZEY, G.; ARONSON, E. (Ed.), The handbook of social psychology. Reading: Addison Wesley, 1969. p.136-314.

MENEZEZ, P. R.; NASCIMENTO, A. de F. Validade e confiabilidade das escalas de avaliação em Psiquiatria. In: GORESTEIN L.ANDRADE, H.S. G \& ZUARDI A. W. (Ed.), Escalas de avaliação clínica em psiquiatria e psicofarmacologia. São Paulo, Lemos Editorial, 2000. p.23-28.

MIGUEL, G. B. Testes psicométricos e projetivos: medidas psicoeducacionais. São Paulo: Loyola, 1983.

MINAYO, M. C. S. Os efeitos da globalização no mundo do trabalho e políticas públicas. In: Seminário Nacional de Diretrizes da Educação em Enfermagem. 1997, Florianópolis. 
MINAYO, M. C. S.; HARTZ, Z. M. A.; BUSS, P. M. Qualidade de vida e saúde: um debate necessário. Rev . Ciências e Saúde Coletiva. v. 5, n. 1, p. 7-18, 2000.

MORIN, E. Ciência com consciência. Rio de Janeiro: Bertrand Brasil, 1996.

Os sete saberes necessários à educação do futuro. São Paulo: Cortez, 2000.

MORSE, J. M. A enfermagem como conforto: um novo enfoque do cuidado profissional. Texto \& Contexto enfermagem. v.7, n.2, p. 70-92, 1998.

. Exploring the theoretical basis of nursing using advanced techniques of concept analysis. Adv. Nurs. Sci., v.17, n.3, p.31-34, 1995.

. Comparative analysis of conceptualizations and theories of caring. Journal of Nursing Scholarship, v.23, n.2, p. 119-26, 1991.

. Concepts of caring and caring as concept. Adv. Nurs. Sci., v. 3, n.1, p. , 1990

NEUMAN, B. The Neuman systems model. East Norkwalk: Appleton \& Lange, 1989.

NEWMAM, M. A. The focus of the discipline of nursing. Adv. Nurs. Sci., v.14, n.1, p. 1-6, 1991.

NIGHTINGALE, F. Notas sobre Enfermagem: o que é e o que não é. São Paulo: Cortez, 1989. 
OMS. Carta de Ottawa. Conferência Internacional para a promoção da saúde: em direção de uma nova saúde pública, 1986.

OREM, D. E. Nursing: concepts of pratice. New York: Mc Graw-Hill, 1985.

ORLANDO, I. J. The discipline and teaching of nursing proces. New York: G.P. Putnam's Sons, 1972.

PACHECO, A. L. P. B. Universidade e a construção de práticas profissionais. Rev. Ed. Ensino - USF, v.6 n.1, p.45-54, 2001.

PASQUALI, L. Princípios de elaboração de escalas psicológicas. In: GORESTEIN L.; ANDRADE, H.S. G.; ZUARDI, A. W.(Ed.) Escalas de Avaliação Clínica em Psiquiatria e Psicofarmacologia. São Paulo: Lemos Editorial, 2000.

Psicometria: teoria e aplicações. Brasília: Editora Universidade de Brasília, 1997.

. Teorias e métodos de medida em ciência do comportamento.

Brasília: Laboratório de Pesquisa em Avaliação e Medida; Instituto de Psicologia/UnB; INEP, 1996.

PATERSON, J.; ZDERAD, L. Humanistic Nursing. New York: Wiley, 1976.

PEPLAU, H. Discurso de agradecimento da sua homenagem. 210 Congresso Quadrienal do CIE. Vancouver, Canadá, 1997.

PESSINI, L. O cuidado em saúde. O Mundo da Saúde, v.24, n.4, 2000. 
RAGAZZI, N. Uma escala de atitude em relação a matemática. São Paulo, 1976. 150f. Dissertação (Mestrado) - Instituto de Psicologia, Universidade de São Paulo.

RICHARDSON, R. J. Pesquisa social: métodos e técnicas. São Paulo: Atlas, 1982.

RODRIGUES, A.R.F. Enfermagem psiquiátrica em saúde mental: prevenção e inter-relacionamento. São Paulo: EPU, 1996.

RODRIGUES, A. R. F. Opções metodológicas de observação das relações interpessoais em enfermagem. Rev. Gaúcha Enf., v. 14, n. 1, p. 61-6, 1993.

ROGERS, C. R. Tornar-se pessoa, São Paulo, Martins Fontes, 1982.

ROGERS, M. E. The theoretical basis of nursing. Philadelphia: F.A. Davis Co, 1970.

ROY, C. Introduction to nursing: an adaptation model. Prentice-Hall, 1984.

SANTO, E. H. F.; ESCUDEIRO, L. C.; CHAGAS, S. A. G. O tom do cuidado de enfermagem para alunos de graduação. Rev. Bras. Enf., v.53, n.1, p.23-9, 2000.

SIEGEL, S. Estatística não paramétrica para as ciências do comportamento. Tradução Alfredo A. de Farias. São Paulo: McGraw-Hill, 1975.

SILVA, A. L. A dimensão humana no cuidado em enfermagem. Acta Paul. Enf., v 13, n.especial, Parte I, p.86-90, 2000. 
SILVA, M. C. From Carper's patterns of knowing to ways of being: an ontological philosophical shift nursing. Adv. Nurs. Sci., v.18, n.1, p.1-13, 1995.

SIQUEIRA, J. E. Ética e tecnociência: uma abordagem segundo o princípio da responsabilidade de Hans Jonas. Londrina: Editora UEL, 1998.

SMITH, M. B.; BRUNER, J. S.; WHITE, R. N. Opinions on personality. New York: John Wiley, 1960.

SUNG e SILVA, A. Conversando sobre ética e sociedade. Petrópolis: Vozes, 1998.

TOFFLER, A. A Terceira Onda. Record: Rio de Janeiro. 23 ed. 1998.

TRAVELBEE, J. Intervencion em enfermeria psiquiátrica. Colômbia: Carvajal, 1982.

UNESCO. Documento de políticas para el cambio y el desarrollo em la educación superior. Paris, 1995.

VANNUCHHI, A. Filosofia e ciências humanas. São Paulo: Loyola, 1977.

VOLICH, R. M. Psicossomática: de Hipócrates à psicanálise. São Paulo: Casa do Psicólogo, 2000.

WALDOW, V. R. Cuidado: uma revisão teórica. Rev. Gaúcha Enf., v.13, n.2, p. 29-35, 1992.

WALDOW, V. R. Cuidado humano: o resgate necessário. 3 ed. Porto Alegre: Saga Luzato, 2001. 
WATSON, J. Nursing: the philosophy and science of caring. Boston: Little Brown, 1979.

WIEDENBACH, E. Comment on beliefs and values: basis for curriculum design. Nursing Research, 1970.

ZANCANARO, L. Cuidando do futuro da vida humana: a ética da responsabilidade de Hans Jonas. O Mundo da Saúde,. v.24, n.4, p.310-20, 2000.

ZUARDI, A. W. (Ed.) Escalas de avaliação clínica em psiquiatria e psicofarmacologia. São Paulo: Lemos Editorial, 2000. 
ANEXOS 
Anexo I

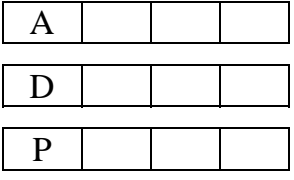

Prezado Sr.

Venho, por este intermédio, solicitar a permissão de Vossa Senhoria para aplicarmos junto aos enfermeiros dessa conceituada Instituição, questionários que irão instrumentalizar o projeto de pesquisa "Avaliação dos significados do cuidado e do cuidar em enfermagem”.

Afirmo que haverá total segurança na manutenção do sigilo e privacidade sobre a origem das respostas, assim como da identificação dos respondentes, que serão seqüenciados por códigos. Tais informações serão analisadas e utilizadas para ensino e pesquisa, com o intuito de contribuir para melhorar a qualidade do ensino e da prática do cuidado em enfermagem.

O projeto tem o parecer favorável do Conselho de Ética em Pesquisa do Centro Universitário Hermínio Ometto, registrado no sob $n^{\circ}$ o qual anexo a este.

No aguardo de vossa resposta, reafirmo minha consideração e elevado apreço.

Atenciosamente,

Rosa Aparecida Pavan Bison

Pesquisadora do Programa de Doutorado do Departamento de Enfermagem Psiquiátrica e Ciências Humanas da Escola de Enfermagem da USP de Ribeirão Preto. 
Anexo II

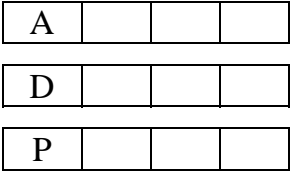

Prezado colega

Você está sendo convidado a participar de um estudo que se propõe a analisar e compreender os significados do cuidado na enfermagem.

Solicitamos que você contribua através do instrumento por nós elaborado, denominado Escala de Avaliação do Significado do Cuidar (EASC).

Assinale a resposta que corresponda à sua opinião sobre o tema, a partir da sua própria vivência.

Os aspectos abordados nessas afirmativas contribuirão para que possamos entender melhor como acontece a relação da enfermagem com o cuidar e para refletirmos sobre a qualidade da assistência de enfermagem.

Você só participa se estiver de acordo. Não haverá riscos, nem desconfortos, nem gastos de qualquer natureza.Você poderá solicitar esclarecimentos quando sentir necessidade, podendo interromper nossas atividades quando quiser.

O que for dito, registrado e escrito será respeitosamente utilizado para fins acadêmicos e científicos, assegurando seu anonimato.

Rosa Aparecida Pavan Bison

Pesquisadora do Programa de Doutorado do Departamento de Enfermagem Psiquiátrica e Ciências Humanas da Escola de Enfermagem da USP de Ribeirão Preto. 


\section{Anexo III}

\section{Esclarecimento ao Sujeito da Pesquisa}

1) Nome da Pesquisa: Avaliação dos significados do cuidado e do cuidar em enfermagem

2) Pesquisadora responsável: Rosa Aparecida Pavan Bison

\section{Consentimento Livre e Esclarecido}

$\mathrm{Eu}$ anos,

recebi todas informações do estudo que pretende analisar nossas opiniões sobre o cuidado na enfermagem. Fui informado de que minha opinião contribuirá para melhorar a qualidade do cuidado de enfermagem. Darei minha opinião na Escala de Avaliação do Significado do Cuidar, a qual será identificada por código, não revelando minha identidade. As informações serão analisadas e serão utilizadas para ensino e pesquisa.

Estou sabendo que, em nenhum momento, serei exposto (a) a riscos devido a minha participação nesta pesquisa. Sei também que a qualquer momento, poderei recusar-me a continuar, sem qualquer prejuízo para minha pessoa. Fui informado que não terei nenhum tipo de despesa, nem receberei nenhum pagamento ou gratificação pela minha participação nessa pesquisa.

Concordo voluntariamente em participar deste estudo.

Assinatura

Rosa Ap. Pavan Bison

RG: 6.184 .543

COREN: 8745

Fone: 541-9386

(Pesquisadora)
Dra. Antonia Regina F. Furegato

RG: 4.415.193-7

COREN: 7599

Fone: 602-3422

(Orientadora) 
Anexo IV

\begin{tabular}{|l|l|l|l|}
\hline $\mathrm{A}$ & & & \\
\hline $\mathrm{D}$ & & & \\
\hline $\mathrm{P}$ & & & \\
\hline
\end{tabular}

\section{Perfil do Entrevistado}

1. Idade:

Série em que estuda: $1^{\mathrm{a}}$

$2^{\mathrm{a}} \square \quad 3^{\mathrm{a}} \square \quad 4^{\mathrm{a}} \square$

2. Sexo: Masculino

Feminino $\square$

3. Estado Civil: Solteiro $\square$

Casado $\square$

Viúvo $\square$

Separado

4. Procedência: Cidade:

Estado:

Área: urbana $\square$

rural $\square$

5. Residência: Araras $\square$

Outra:

6. Moradia: Família

Outro $\square$

7. Transporte: Próprio

Coletivo

Público

8. Trabalha na área de enfermagem: Sim

Não

9. Renda Familiar:

10. Número de pessoas que vivem com a renda: 
Perfil do Entrevistado

\begin{tabular}{|l|l|l|l|}
\hline $\mathrm{A}$ & & & \\
\hline $\mathrm{D}$ & & & \\
\hline $\mathrm{P}$ & & & \\
\hline
\end{tabular}

1. Idade:

2. Sexo: Masculino

Feminino $\square$

3. Estado Civil: Solteiro $\square \quad$ Casado $\square \quad$ Viúvo $\square \quad$ Separado

4. Procedência: Cidade:

Estado:

Área: urbana $\square \quad$ rural $\square$

5. Residência: Araras $\square$

Outra:

6. Moradia: Família $\square \quad$ República $\square \quad$ Sozinho $\square \quad$ Outro $\square$

7. Transporte: Próprio $\square \quad$ Coletivo $\square \quad$ Público

8. Ano em que se formou enfermeiro:

9. Tempo que trabalha na área de enfermagem: anos

10. Áreas em que atuou ou atua: Assistência $\square \quad$ Ensino $\square \quad$ Pesquisa

11. Curso de pós-graduação:

Concluído $\square$
Especialização - ano
Mestrado - ano
Doutorado - ano

Em andamento $\square$

Não

12. Renda Familiar:

13. Número de pessoas que vivem com a renda: 


\section{Escala de Avaliação do Significado do Cuidar - EASC}

Este questionário é composto por 45 afirmativas. Leia cuidadosamente cada uma e assinale com um círculo a opção que melhor representa a sua opinião (discordo totalmente, discordo, em dúvida, concordo, concordo totalmente).

1. Manter as próprias unhas cuidadas é importante.

\begin{tabular}{l|l|l}
\hline Discordo & Em dúvida
\end{tabular}

\begin{tabular}{l|l} 
Concordo & Concordo totalmente \\
\hline
\end{tabular}

2. O enfermeiro não deve expressar seus sentimentos durante o cuidado.

Discordo totalmente

Concordo totalmente

3. Exercer a enfermagem é uma atividade difícil.

\begin{tabular}{|l|l|l|l|l} 
Discordo totalmente & Discordo & Em dúvida & Concordo & Concordo totalmente
\end{tabular}

4. Estou sempre atenta às alterações da minha saúde.

Discordo totalmente

\begin{tabular}{l|l|l|l} 
Discordo & Em dúvida & Concordo & Concordo totalmente
\end{tabular}

5. O ato de cuidar exige competência.

\begin{tabular}{l|c|c|c|c|} 
Discordo totalmente & Discordo & Em dúvida & Concordo & Concordo totalmente \\
\hline
\end{tabular}

6. Dormir bem todos os dias é fundamental.

\begin{tabular}{|c|c|c|c|c|}
\hline Discordo totalmente & Discordo & Em dúvida & Concordo & Concordo totalmente \\
\hline
\end{tabular}

7. Minha alimentação diária é equilibrada.

\begin{tabular}{|l|c|c|c|c|}
\hline Discordo totalmente & Discordo & Em dúvida & Concordo & Concordo totalmente \\
\hline
\end{tabular}

8. Ao cuidar, o enfermeiro deve ser imparcial.

\begin{tabular}{|c|c|c|c|c|}
\hline Discordo totalmente & Discordo & Em dúvida & Concordo & Concordo totalmente \\
\hline
\end{tabular}

9. A meiguice precisa estar presente no ato de cuidar.

\begin{tabular}{l|l|l} 
Discordo totalmente & Discordo & Em dúvida
\end{tabular}

10. Cuidar é um ato de compaixão.

\begin{tabular}{|l|c|c|c|c|}
\hline Discordo totalmente & Discordo & Em dúvida & Concordo & Concordo totalmente \\
\hline
\end{tabular}

11. A aparência pessoal é importante para o cuidado.

\begin{tabular}{|c|c|c|c|c|}
\hline Discordo totalmente & Discordo & Em dúvida & Concordo & Concordo totalmente \\
\hline
\end{tabular}

12. Quem cuida deve saber o que o paciente pensa sobre as próprias necessidades.

\begin{tabular}{l|c|c|c|c} 
Discordo totalmente & Discordo & Em dúvida & Concordo & Concordo totalmente
\end{tabular}

13. A relação de empatia com o outro é importante no cuidado.

\begin{tabular}{|l|c|c|c|c|} 
Discordo totalmente & Discordo & Em dúvida & Concordo & Concordo totalmente \\
\hline
\end{tabular}

14. Cuidar do próprio corpo é importante.

Discordo totalmente Discordo Em dúvida Concordo Concordo totalmente 
15. Cuidar envolve compromisso de um ser humano para com outro.

\begin{tabular}{|c|c|c|c|c|}
\hline Discordo totalmente & Discordo & Em dúvida & Concordo & Concordo totalmente \\
\hline
\end{tabular}

16. O cuidado envolve afetividade.

\begin{tabular}{|l|c|c|c|c|} 
Discordo totalmente & Discordo & Em dúvida & Concordo & Concordo totalmente \\
\hline
\end{tabular}

17. Eu gosto de ser enfermeiro.

\begin{tabular}{|l|c|c|c|c|} 
Discordo totalmente & Discordo & Em dúvida & Concordo & Concordo totalmente \\
\hline
\end{tabular}

18. O cuidar envolve manejo adequado das situações que se apresentam.

\begin{tabular}{|c|c|c|c|c|}
\hline Discordo totalmente & Discordo & Em dúvida & Concordo & Concordo totalmente \\
\hline
\end{tabular}

19. O enfermeiro deve ser bem-humorado no desempenho do cuidado.

\begin{tabular}{|c|c|c|c|c|}
\hline Discordo totalmente & Discordo & Em dúvida & Concordo & Concordo totalmente \\
\hline
\end{tabular}

20. Cuidar envolve organização.

\begin{tabular}{|l|c|c|c|c|} 
Discordo totalmente & Discordo & Em dúvida & Concordo & Concordo totalmente \\
\hline
\end{tabular}

21. Cuidar envolve gentileza.

\begin{tabular}{l|c|c|c|c} 
Discordo totalmente & Discordo & Em dúvida & Concordo & Concordo totalmente
\end{tabular}

22. Cuidar envolve o ideal de servir.

\begin{tabular}{|c|c|c|c|c|}
\hline Discordo totalmente & Discordo & Em dúvida & Concordo & Concordo totalmente \\
\hline
\end{tabular}

23. Sendo impessoal, o enfermeiro cuida melhor.

\begin{tabular}{|c|c|c|c|c|}
\hline Discordo totalmente & Discordo & Em dúvida & Concordo & Concordo totalmente \\
\hline
\end{tabular}

24. O cuidado exige destreza.

\begin{tabular}{|l|c|c|c|c|} 
Discordo totalmente & Discordo & Em dúvida & Concordo & Concordo totalmente \\
\hline
\end{tabular}

25. O cuidado envolve real interesse de quem cuida.

\begin{tabular}{|c|c|c|c|c|}
\hline Discordo totalmente & Discordo & Em dúvida & Concordo & Concordo totalmente \\
\hline
\end{tabular}

26. O cuidado deve ser planejado.

Discordo totalmente $\quad$ Discordo

27. Para cuidar, o enfermeiro deve observar as normas institucionais.

\begin{tabular}{|c|c|c|c|c|}
\hline Discordo totalmente & Discordo & Em dúvida & Concordo & Concordo totalmente \\
\hline
\end{tabular}

28. A percepção que o cliente tem do enfermeiro interfere no cuidado.

\begin{tabular}{l|c|c|c|c} 
Discordo totalmente & Discordo & Em dúvida & Concordo & Concordo totalmente
\end{tabular}

29. Educação deve fazer parte do cuidado de enfermagem.

\begin{tabular}{|l|c|c|c|c|}
\hline Discordo totalmente & Discordo & Em dúvida & Concordo & Concordo totalmente \\
\hline
\end{tabular}

30. A atividade física faz parte do meu cuidado pessoal.

\begin{tabular}{|c|c|c|c|c|}
\hline Discordo totalmente & Discordo & Em dúvida & Concordo & Concordo totalmente \\
\hline
\end{tabular}

31. O bom cuidado depende da execução correta das técnicas de enfermagem.

\begin{tabular}{|l|c|c|c|c|} 
Discordo totalmente & Discordo & Em dúvida & Concordo & Concordo totalmente \\
\hline
\end{tabular}

32. O código de ética da enfermagem deve ser colocado em prática no cuidar.

\begin{tabular}{|l|c|c|c|c|}
\hline Discordo totalmente & Discordo & Em dúvida & Concordo & Concordo totalmente \\
\hline
\end{tabular}


33. O cuidado não tem preço.

\begin{tabular}{|l|c|c|c|c|} 
Discordo totalmente & Discordo & Em dúvida & Concordo & Concordo totalmente \\
\hline
\end{tabular}

34. Para cuidar, o enfermeiro utiliza procedimentos metódicos.

\begin{tabular}{l|c|c|c|c} 
Discordo totalmente & Discordo & Em dúvida & Concordo & Concordo totalmente
\end{tabular}

35. O hábito da auto-medicação é prejudicial.

\begin{tabular}{l|c|c|c|c|} 
Discordo totalmente & Discordo & Em dúvida & Concordo & Concordo totalmente \\
\hline
\end{tabular}

36. Quem cuida precisa ter responsabilidade, respeito e honestidade.

\begin{tabular}{l|c|c|c|c} 
Discordo totalmente & Discordo & Em dúvida & Concordo & Concordo totalmente
\end{tabular}

37. Ao cuidar o enfermeiro deve valorizar a comunicação.

\begin{tabular}{|c|c|c|c|c|}
\hline Discordo totalmente & Discordo & Em dúvida & Concordo & Concordo totalmente \\
\hline
\end{tabular}

38. Conhecer os direitos e os deveres do cidadão para praticar o cuidado é importante.

\begin{tabular}{l|c|c|c|c} 
Discordo totalmente & Discordo & Em dúvida & Concordo & Concordo totalmente
\end{tabular}

39. Cuidar envolve delicadeza.

\begin{tabular}{|l|c|c|c|c|} 
Discordo totalmente & Discordo & Em dúvida & Concordo & Concordo totalmente \\
\hline
\end{tabular}

40. A relação de confiança é necessária para o cuidado.

\begin{tabular}{|c|c|c|c|c|}
\hline Discordo totalmente & Discordo & Em dúvida & Concordo & Concordo totalmente \\
\hline
\end{tabular}

41. Reservar algum tempo para o próprio lazer é importante.

\begin{tabular}{|c|c|c|c|c|}
\hline Discordo totalmente & Discordo & Em dúvida & Concordo & Concordo totalmente \\
\hline
\end{tabular}

42. Quem cuida deve considerar os valores do outro.

\begin{tabular}{|c|c|c|c|c|}
\hline Discordo totalmente & Discordo & Em dúvida & Concordo & Concordo totalmente \\
\hline
\end{tabular}

43. Quem cuida deve estar bem consigo mesmo.

\begin{tabular}{|c|c|c|c|c|}
\hline Discordo totalmente & Discordo & Em dúvida & Concordo & Concordo totalmente \\
\hline
\end{tabular}

44. O cuidado envolve perspicácia do enfermeiro.

\begin{tabular}{l|c|c|c|c|} 
Discordo totalmente & Discordo & Em dúvida & Concordo & Concordo totalmente
\end{tabular}

45. Cuidar é sinal de solidariedade.

Discordo totalmente $\quad$ Discordo

\begin{tabular}{l|l|l} 
Em dúvida & Concordo & Concordo totalmente
\end{tabular}

